\title{
Revision of the Late Jurassic crocodyliform Alligatorellus, and evidence for allopatric speciation driving high diversity in western European atoposaurids
}

Atoposaurid crocodyliforms represent an important faunal component of Late Jurassic to Early Cretaceous Laurasian semi-aquatic to terrestrial ecosystems, with numerous spatiotemporally contemporaneous atoposaurids known from western Europe. In particular, the Late Jurassic of France and Germany records evidence for high diversity and possible sympatric atoposaurid species belonging to Alligatorellus, Alligatorium and Atoposaurus. However, atoposaurid taxonomy has received little attention, and many species are in need of revision. As such, this potentially high European diversity within a narrow spatiotemporal range might be a taxonomic artefact. Here we provide a taxonomic and anatomical revision of the Late Jurassic atoposaurid Alligatorellus. Initially described as $A$. beaumonti from the Kimmeridgian of Cerin, eastern France, additional material from the Tithonian of Solnhofen, south-eastern Germany, was subsequently referred to this species, with the two occurrences differentiated as $A$. beaumonti beaumonti and $A$. beaumonti bavaricus, respectively. We provide a revised diagnosis for the genus Alligatorellus, and note a number of anatomical differences between the French and German specimens, including osteoderm morphology and the configuration and pattern of sculpting of cranial elements. Consequently, we restrict the name Alligatorellus beaumonti to include only the French remains, and raise the rank of the German material to a distinct species: Alligatorellus bavaricus. A new diagnosis is provided for both species, and we suggest that a recently referred specimen from a coeval German locality cannot be conclusively referred to Alligatorellus. Although it has previously been suggested that Alligatorellus, Alligatorium and Atoposaurus might represent a single growth series of one species, we find no conclusive evidence to support this proposal, and 
provide a number of morphological differences to distinguish these three taxa that appear to be independent of ontogeny. Consequently, we interpret high atoposaurid diversity in the Late Jurassic island archipelago of western Europe as a genuine biological signal, with closely related species of Alligatorellus, Alligatorium and Atoposaurus in both French and German basins providing evidence for allopatric speciation, potentially driven by fluctuating highstand sea levels. 
1 Jonathan P. Tennant* and Philip D. Mannion

2 Department of Earth Science and Engineering, Imperial College London, London, 3 SW7 2AZ, UK

4 Corresponding author: *jonathan.tennant10@imperial.ac.uk 
Introduction

Atoposaurids comprise a clade of small-bodied terrestrial and semi-aquatic crocodyliforms (Owen, 1879; Joffe, 1967; Buscalioni and Sanz, 1990a; Thies et al., 1997; Lauprasert et al., 2011). Historically, they were considered to be the sister group to Eusuchia (Joffe, 1967; Buffetaut, 1982), but are now recovered in all phylogenetic analyses as the basal-most members of Neosuchia, which includes crown group crocodylians (Benton and Clark, 1988; Buscalioni and Sanz 1990b; Salisbury et al., 2006; Brochu et al., 2009; Pol and Gasparini, 2009; Adams, 2013; Sertich and O'Connor, 2014). Atoposaurids were an important component of a range of Late Jurassic to Early Cretaceous western European ecosystems (Fig. 1), with less common occurrences extending their known stratigraphic range from the Middle Jurassic to the end-Cretaceous (168.3-66 million years ago [Ma]; Fig. 2) (Owen, 1879; Buscalioni and Sanz, 1984, 1987a; Salisbury, 2002; Martin et al., 2010; Salisbury and Naish, 2011). There is tentative evidence to suggest that atoposaurids might have persisted beyond the Cretaceous/Paleogene boundary, based on fragmentary material from the Middle Eocene of the Republic of Yemen (Stevens et al., 2013). The earliest known atoposaurid specimens are Theriosuchus-like teeth from the early (Kriwet et al., 1997) and middle (Knoll et al., 2013) Bathonian (late Middle Jurassic) of southern France and the Bathonian of the UK (Evans and Milner, 1994), with Theriosuchus sympiestodon from the Maastrichtian of Romania the last known occurrence (Martin et al., 2010; 2014). Other putative and fragmentary occurrences potentially extend the distribution of Atoposauridae into the Late Jurassic-Early Cretaceous of Asia (Young 1961; Efimov, 1976; Wu et al., 1994, 1996, 1997; Storrs and Efimov, 2000; Cuny et al., 2010; Wings et al., 2010) and North America (Gilmore, 1926; Cifelli et al., 1999; Eaton et al., 1999; Fiorillo, 1999; Rogers, 2003), and a late Early Cretaceous occurrence, Brillanceausuchus babouriensis, from Cameroon, might represent evidence for the presence of the clade in Gondwana (Michard et al., 1990).

Despite this research history and range of recent discoveries, there is currently little species-level taxonomic clarity or consensus on atoposaurid interrelationships (Owen, 1878, 1879; Wellnhofer, 1971; Buffetaut, 1982; Clark, 1986; Buscalioni and Sanz, 1988; Brinkmann, 1989, 1992; Wu et al., 1996; Schwarz and Salisbury, 2005). Steel (1973) considered Atoposauridae to comprise Alligatorellus, 
39 Alligatorium, Atoposaurus, Hoplosuchus, Shantungosuchus, and Theriosuchus. More 40 recently, Lauprasert et al. (2011) recognised only four valid genera, Alligatorellus, 41 Alligatorium, Montsecosuchus, and Theriosuchus, with the latter genus comprising 42 four species: T. grandinaris, T. guimarotae, T. ibericus and T. pusillus. Martin et al. 43 (2010) augmented this species list with their description of T. sympiestodon from the 44 Maastrichtian of Romania. Schwarz-Wings et al. (2011) followed this taxonomic 45 scheme, but also regarded Atoposaurus as a valid genus, comprising the two 46 species $A$. jourdani and $A$. oberndorferi. There are three currently recognised species 47 of Alligatorium: A. meyeri from France (Vidal, 1915) and A. franconicum (Ammon, 48 1906) and $A$. paintenense (Kuhn, 1961; originally described by Broili [1931] as a 49 possible occurrence of $A$. franconicum) from Germany. However, specimens of the 50 latter two were lost or destroyed during World War II. An Early Cretaceous Spanish 51 species originally placed in Alligatorium has since been assigned to a new genus, 52 Montsecosuchus (Vidal, 1915; Peybernes and Oertli, 1972; Buscalioni and Sanz, 53 1988, 1990a).

Gervais (1871) originally erected the species name Alligatorellus beaumonti 55 for two specimens from the Late Jurassic of Cerin, in eastern France. Wellnhofer 56 (1971) later assigned these specimens to the subspecies A. beaumonti beaumonti, 57 in recognition of differences between coeval specimens from Eichstätt, southeast Germany, for which he erected the subspecies $A$. beaumonti bavaricus. Both the French and German specimens have been regarded as Alligatorellus beaumonti by subsequent workers (e.g., Buscalioni and Sanz, 1988; Schwarz-Wings et al., 2011). As a result of these factors, the species-level composition and relationships of Alligatorellus, Alligatorium and Atoposaurus, as well as the Spanish Montsecosuchus depereti, remains poorly understood. This in part reflects a paucity of specimens, but also the flattened mode of preservation of the specimens concerned, which often obscures much of their morphology (Meyer, 1850, 1851; Gervais, 1871; Wellnhofer, 1971; Buscalioni and Sanz, 1990a). This taphonomic signature results from their exclusive occurrence in lithographic limestones. Furthermore, Theriosuchus appears to have become a 'waste-basket taxon' for recently 69 discovered small, basal neosuchian specimens from Asia and Europe. Unlike Alligatorellus, Alligatorium, Atoposaurus and Montsecosuchus which occur in lagoonal settings, Theriosuchus occurs in a range of transitional brackish onshore or near-shore environments (Schwarz and Salisbury, 2005; Lauprasert et al., 2011). 
Given such potentially high European atoposaurid diversity within a narrow geographic and temporal range, and a lack of taxonomic consensus, a full revision of atoposaurid systematics is overdue. Presented here is a re-assessment of specimens of Alligatorellus from the Late Jurassic of France and Germany in the first of a series of papers in which we will revise the taxonomy, systematics and phylogenetic relationships of Atoposauridae. We refer the German occurrence to a new species of Alligatorellus, providing a comprehensive re-description, and make detailed comparisons with the French type species. We also consider the taxonomic affinities of an additional German specimen described as Alligatorellus sp. (Schwarz-Wings et al., 2011), and examine the osteoderm morphology of Alligatorellus, investigating its utility in atoposaurid systematics. Finally, we examine the taxonomy and validity of the contemporaneous, multispecific taxa Alligatorium and Atoposaurus, and discuss the diverse atoposaurid faunal composition of the Late Jurassic of western Europe.

\section{Institutional Abbreviations}

LMU, Ludwig-Maximilians Universitat, Bayerische Staatssammlung für Paläontologie MNHN, Muséum National d'Histoire Naturelle, Centre de Conservacion, Lyon, France; NHMUK, Natural History Museum, London, UK; TMH, Teylers Museum, Haarlem, The

\section{Netherlands.}

\section{Anatomical Abbreviations}

Abbreviations: Af, antorbital fenestra; Cav, caudal vertebra; Cev, cervical vertebra; Ch, chevron; C, coracoid; Co, caudal osteoderm; Do, dorsal osteoderm; Dov, dorsal vertebra; Dr, dorsal ridge; Ds, dermal sculpting; En, external nares; Fi, fibula; Fr, frontal; Hu, humerus; II, ilium; Is, ischium; Ju, jugal; La, lacrimal; Ltf, lateral temporal fenestra; Ma, manus; Man, mandible; Max, maxilla; Mp, manual phalanx; MT, metatarsal; Na, nasal; No, nuchal osteoderm; Or, orbit; Pa, parietal; Pal, palatine; Pe, pes; Pmn, premaxilla-maxilla notch; Pmx, premaxilla; Po, postorbital; Pp, pedal phalanx; Pu, pubis; Ra, radius; Qj, quadratojugal; Qu, quadrate; Rad, radiale; Ri, rib; Sc, scapula; So, sacral osteoderm; Sof, suborbital fenestra; Sq, squamosal; Stf, supratemporal fenestra; Sym, symphysis; Ti, tibia; UI, ulna; UIn, ulnare; Up, ungual phalanx.

\section{Systematic Palaeontology}




\section{PeerJ Reviewing Manuscript}

105

106

107

108

109

110
Crocodylomorpha Walker 1970

Crocodyliformes Hay 1930

Mesoeucrocodylia Whetstone and Whybrow 1983

Neosuchia Benton and Clark 1988

Atoposauridae Gervais 1871

Alligatorellus Gervais 1871

111 Note on taxonomy: Gervais (1871) did not designate a holotype specimen in his

112 original description of Alligatorellus beaumonti. Wellnhofer (1971) elected MNHN

11315639 as the holotype of $A$. beaumonti beaumonti. As this is one of the two

114 specimens described by Gervais (1871), we follow Wellnhofer (1971) in considering

115 MNHN 15639 to be the holotype for the genus and type species of Alligatorellus 116 beaumonti.

117 Wellnhofer (1971, p. 144) provided the following diagnosis of Alligatorellus

118 (translation adapted from Schwarz-Wings et al. 2011): (1) a large-sized atoposaurid

119 (420-550mm) with an acute-triangular skull and large orbits; (2) the supratemporal

120 fossae are not internally fenestrated, and are connected to the orbit by a superficial

121 furrow; (3) the nasal aperture is divided; (4) the tail is longer than half of the 122 precaudal body length; (5) presence of a biserial osteoderm shield from the nuchal 123 to the caudal region; (6) single osteoderms are sculpted; (7) presence of a lateral 124 keel on the nuchal and dorsal osteoderms, whereas the caudal osteoderms bear a 125 more medial keel; (8) ventral armour possesses two rows of scutes in the tail region;

126 (9) the ventral scutes are oval and medially keeled.

127 Comments: In light of more recent atoposaurid discoveries and an improved 128 understanding of their anatomy, much of Wellnhofer's (1971) diagnosis requires 129 revision. The first putative defining characteristic (1) is a feature that also describes

130 the sizes of Alligatorium meyeri, A. franconicum, Montsecosuchus depereti, and

131 Theriosuchus pusillus, and may in fact be an over-estimation of their size. The lack

132 of internal fenestration (2) of the supratemporal fenestra is not seen in other

133 atoposaurids, including Alligatorium, Montsecosuchus, and Theriosuchus, and is thus

134 retained as a locally diagnostic feature. The division of the nasal aperture (3) is not

135 visible in LMU 1937 I 26 as a result of crushing of the anterior-most portion of the

136 snout, but is present in MNHN 15639. Regardless, this appears to be a feature

137 shared by other atoposaurids including Theriosuchus pusillus (NHMUK PV OR48330)

138 and Theriosuchus grandinaris (Lauprasert et al., 2011). The relative length of the tail 
139 (4) is a feature seen in other atoposaurids including Atoposaurus and Theriosuchus 140 pusillus and appears to be widespread among Atoposauridae, as are characters (5)

141 and (6). Indeed, osteoderm sculpting and a biserial osteodermal shield are present 142 in Alligatorium, Montsecosuchus, and Theriosuchus. The presence, prominence, and 143 position of a dorsal keel on the biserial osteoderms might be diagnostic at the 144 generic level (7), although there are differences between the German and French 145 specimens, as discussed below. The presence of a dual row of ventral osteoderms in 146 the caudal region is also questionable (8), especially with respect to their 147 morphology (9) - they are rarely and poorly preserved in the ventral region in both 148 French and German specimens. It is probable that post-mortem flattening has re149 arranged the paravertebral dorsal osteoderms, which, when viewed laterally, might 150 easily be misinterpreted as belonging to a ventral series. Finally, it should be noted 151 that in the referred specimen of $A$. beaumonti (MNHN 15638), the osteoderms are 152 much less visible, with just a single noticeable row overlying the anterior caudal 153 vertebrae, and possibly a single row concealed underneath the dorsal vertebrae.

154 Revised diagnosis: Among currently recognised atoposaurids, Alligatorellus 155 can be diagnosed based on the following unique combination of features and 156 autapomorphies (highlighted with an asterisk): (1) rostrum unsculpted or 157 substantially less so than cranial table; (2) cranial sculpting comprised of 158 homogeneous shallow pitting; (3) absence of hypertrophied maxillary tooth 5, with 159 homodont pseudocaniniform dentition; (4) frontal width between the orbits narrower 160 than maximal width of nasals; $\left(5^{*}\right)$ broad frontal anterior process, not constricted; 161 (6) absence of raised orbital or supratemporal rims; (7) unperforated supratemporal 162 fenestra; $\left(8^{*}\right)$ anterior process of squamosal extends to the orbital margin; (9*) 163 posterodorsal margin of parietals and squamosals completely covers dorsal occipital 164 region; (10) smooth mandibular outer surface; (11) proportionally short first 165 metatarsal; (12) dorsal surface of dorsal osteoderms completely sculpted, with 166 parallel and straight anterior and posterior margins; (13*) dorsal osteoderms with 167 longitudinal ridge along entire lateral margin; (14) caudal osteoderms with smooth, 168 non-serrated edges. 
171 Holotype: MNHN 15639, part and counterpart slabs preserving a near-complete,

172 articulated skull and skeleton, missing the distal forelimb elements and part of the 173 left hindlimb (Fig. 3).

174 Referred specimen: MNHN 15638, part slab comprising a near-complete articulated 175 skeleton, missing the distal-most caudal vertebrae and part of the left forelimb (Fig. 176 4).

177 Locality and stratigraphic age: Cerin, Ain, eastern France; Kimmeridgian (Late 178 Jurassic) (Wellnhofer, 1971).

179 Preservation of holotype: The specimen is dorsolaterally flattened and, on the part, 180 the dorsal surface of the skull is embedded into matrix comprising grey lithographic 181 limestone. This obscures both the lateral and ventral surfaces, and much of the 182 mandible. Thirteen maxillary teeth are preserved. The complete, articulated axial 183 skeleton is preserved, with the exception of the three posterior-most caudal 184 vertebrae, and is overlain by a continuous sheath of parasagittal biserial 185 osteoderms. At least eleven ribs are preserved in situ on the left hand side. A partial 186 right scapula is the only preserved element of the pectoral girdle. The right forelimb 187 is missing the proximal humerus and manus, and the left forelimb is disarticulated, 188 lacking the manus. Some fragmentary pelvic elements remain, including both ilia. 189 The left hindlimb is articulated but damaged, missing part of the femoral midshaft, 190 the proximal tibia and fibula, and distal tarsals. The right hindlimb is articulated but 191 missing both the proximal femur and the distal phalanx on digit I. The counterpart 192 preserves two osteoderms and fragments of skull material embedded within the 193 impressions. There is some dendritic mineral growth propagating from the skeleton.

194 Preservation of referred specimen: The entire skeleton is laterally flattened on 195 a brick-red and grey slab of lithographic limestone. No counterpart is preserved. The 196 skull is ventrolaterally flattened, exposing only the ventral and sinistral sides of the 197 mandible, the ventrolateral portion of the skull, and nine maxillary teeth. The right 198 forelimb is preserved only as an impression, as are the posterior-most caudal 199 vertebrae. Otherwise, the entire axial skeleton is preserved, together with three ribs 200 (and several rib impressions), and the left pectoral and pelvic girdles. Both hindlimbs 201 are complete. A single row of osteoderms is preserved along the nuchal-dorsal 202 series. The cervical vertebrae are recurved slightly posteriorly, and the 
203 posteroventrally deflected limbs give the impression of hanging loosely from the 204 trunk.

205 Additional comments: Wellnhofer (1971) provided a detailed description of 206 both specimens of Alligatorellus beaumonti. Here, we provide only a revised 207 diagnosis as the basis for its taxonomic discrimination from the Bavarian specimens 208 of Alligatorellus. Using linear morphometrics, Wellnhofer (1971) regarded the Cerin 209 and Bavarian specimens to be of similar, adult ages, and largely based his 210 justification for recognising two distinct taxa on the relatively smaller size of the 211 Cerin specimens (which are approximately $50 \mathrm{~mm}$ shorter in total length). However, 212 size and geographical distribution are not the only attributes demarcating the two as 213 distinct taxa, as outlined below.

214 Revised diagnosis: Alligatorellus beaumonti can be diagnosed based on the 215 following unique combination of characters and autapomorphies (highlighted with 216 an asterisk): (1) smooth contact between maxilla and jugal (Fig. 6); (2*) frontal with 217 unsculpted posterior and anterior portions; (3) surface of rostrum notably less 218 sculpted than cranial table; (4) relatively large lateral temporal fenestra, 219 approximately $30 \%$ the size of the orbit; $\left(5^{*}\right)$ medial longitudinal depression on 220 posterior portion of nasal and anterior portion of frontal; $\left(6^{*}\right)$ frontal width between 221 orbits narrower than nasals; (7) smooth and unsculpted region on anterior portion of 222 squamosal nearing orbit and posterolateral process of squamosal; (8*) vertebral 223 centra shape grades continuously posteriorly from cylindrical to elongate-spool; (9) 224 secondary osteoderms in caudal series present; $\left(12^{*}\right)$ lateral ridge on sacral 225 osteoderms forms an incipient posterior projection; (10) ratio of femur to tibia high 226 (1.11).

227

228

229

230

231

232
Alligatorellus bavaricus Wellnhofer 1971 Alligatorellus beaumonti bavaricus Wellnhofer 1971

Note on taxonomy: Wellnhofer (1971) regarded LMU 1937 I 26 as the holotype of $A$. beaumonti bavaricus, and we elect this specimen as the holotype of $A$. bavaricus, which we re-rank from subspecies to species level.

Holotype specimen: LMU 1937 I 26 (Fig. 5). 
233 Referred specimen: Wellnhofer (1971) also described a second specimen of $A$.

234 bavaricus, held in the private collection of E. Schöpfel. Based on the images and

235 description provided by Wellnhofer (1971), we follow this referral. However, in view

236 of the fact that this specimen remains in a private collection and is not publicly

237 accessible, this referral is informal and is used only to draw attention to the

238 existence of a second specimen.

239 Type locality and horizon: Solnhofen beds near Eichstätt, southeast Germany; early

240 Tithonian (Late Jurassic, Hybonoticeras hybonotum zone; Wellnhofer, 1971).

241 Preservation: The specimen is a semi-three-dimensional body fossil preserved 242 obliquely on a slab of Solnhofen 'Plattenkalk', and is fully articulated with its head 243 dorsally recurved. As preserved, the spinal column is rod-like with a slight ventral 244 flex, and the limbs are splayed out beneath the trunk. Trunk elements (posterior 245 cervical and dorsal vertebrae, ribs, and osteoderms) are mostly damaged and 246 crushed beyond recognition in an agglomeration, where there is a noticeable trace 247 of soft tissue residue. Poor skeletal preservation means that the anterior-most 248 vertebrae (atlas, axis, and anterior cervical vertebrae) are indistinguishable from 249 one another. Only the eleven anterior-most dorsal paravertebral osteoderms are 250 substantially preserved with a minor and variable degree of caudal imbrication. The 251 next four osteoderms in the series are missing (anteriorly adjacent to the sacrum), 252 but twenty five paired osteoderms are preserved along the tail. Poorly preserved 253 ventral osteoderms are part of the agglomeration around the torso, and are present 254 along the sacrum and tail. The ventral osteoderms terminate posteriorly at the same 255 position as the dorsal series.

256 Etymology of species name: bavaricus, based on the area of the type locality, and 257 also the sub-species name provided by Wellnhofer (1971) for this specimen.

258 Additional comments: The majority of the features Wellnhofer (1971) proposed in 259 the original diagnosis of $A$. bavaricus characterise atoposaurids in general, or are 260 more widespread within Atoposauridae. For example, an 'acute-triangular skull with 261 large orbit' is a general feature seen in many crocodyliforms, including all known 262 atoposaurids and bernissartiids, and the 'biserial osteoderm shield from the nuchal 
263 to caudal region' is found in the atoposaurids Theriosuchus (Owen, 1879) and

264 Alligatorium (Wellnhofer, 1971), and may be synapomorphic for Atoposauridae.

Diagnosis: Alligatorellus bavaricus can be diagnosed based on the following 266 unique combination of characters and autapomorphies (highlighted with an 267 asterisk): $\left(1^{*}\right)$ extremely narrow and short skull (ratio of skull width to orbit length is 268 1.29; Fig. 7); (2*) posterior surface of nares longitudinally crenulated; (3) small, slit269 shaped antorbital fenestra, enclosed by nasals; $\left(4^{*}\right)$ prominent transverse ridge 270 defining frontal-parietal suture, medial to supratemporal fenestrae; (5) smooth 271 posterior region of parietal dorsal surface; (6*) dorsal osteoderms with longitudinal 272 medial ridge, becoming more laterally placed anteriorly; (7) isometric caudal 273 osteoderm morphology; (8*) distinct ridge on proximodorsal edge of scapula; (9*) an 274 extremely high humerus to ulna ratio of 1.45; (10*) an extremely low femur to tibia 275 ratio of $1.04 ;\left(11^{*}\right)$ an extremely low tibia to ulna ratio of 0.64 ; (12) metatarsals I-IV 276 equidimensional.

277 Differential diagnosis to $A$. beaumonti: Alligatorellus bavaricus can be 278 distinguished from $A$. beaumonti based on possessing the following features: (1) 279 proportionally larger orbits; (2) longitudinal crenulations on the posterior external 280 surface of the nares; (3) a diminutive antorbital fenestra; (4) frontals proportionally 281 wider between orbits than nasals; (5) prominent transverse ridge defining the 282 frontal-parietal suture on the cranial table; (6) lack of posterolateral squamosal 283 process; (7) medially-placed dorsal keels on dorsal osteoderms; (8) osteoderm 284 shapes are isometric down length of body; (9) humerus proportionally longer than ulna (1.45 to 1.12); (10) higher ratio of humerus to femur length (0.89 to 0.75 ).

The electronic version of this article in Portable Document Format (PDF) will represent a published work according to the International Commission on Zoological Nomenclature (ICZN), and hence the new names contained in the electronic version are effectively published under that Code from the electronic edition alone. This published work and the nomenclatural acts it contains have been registered in ZooBank, the online registration system for the ICZN. The ZooBank LSIDs (Life Science Identifiers) can be resolved and the associated information viewed through any standard web browser by appending the LSID to the prefix "http://zoobank.org/". The LSID for this publication is: urn:Isid:zoobank.org:pub:B7CC4367-4203-4AED8C30-2D7E4E71665D. The online version of this work is archived and available from the following digital repositories: PeerJ, PubMed Central and CLOCKSS.

\section{Description and comparisons of Alligatorellus bavaricus}

298 The following description is solely of the type specimen LMU 1937 I 26 but, 299 based on the images presented in Wellnhofer (1971), the referred specimen does 300 not appear to differ in any notable way. Elements of the skull of the type are fully 
301 fused, and vertebrae display complete neurocentral fusion, implying that this 302 specimen of Alligatorellus had reached a mature stage of growth (Joffe, 1967). 303 Measurements are provided in Table 1.

304 Skull: Observations of the skull are restricted to the dorsal and right-lateral 305 surfaces. These external surfaces display a moderate degree of sculpting, although 306 to a lesser extent than that of Theriosuchus (Owen, 1879; Brinkmann, 1992; Wu et 307 al., 1996; Schwarz and Salisbury, 2005) and Alligatorium (Wellnhofer, 1971). The 308 skull has an acute-triangular morphology (platyrostral) in dorsal view, typical of 309 atoposaurids, with concave lateral margins along the relatively short snout. The 310 intramandibular angle (defined as the angle between the lateral extremities of the 311 cranial table and the distal snout tip, in dorsal aspect) is slightly greater $\left(37^{\circ}\right)$ than 312 that of Theriosuchus $\left(30-32^{\circ}\right)$. Several teeth are preserved in situ, and are peg-like 313 (pseudocaniniform), pointed and possess apicobasally and mesiodistally oriented, 314 parallel striations. None of the teeth appear to be serrated, and in general aspect 315 they are indistinguishable from the teeth observed in the Cerin specimens of 316 Alligatorellus beaumonti. Alligatorellus bavaricus may possess one more maxillary 317 tooth than the French species, although this is difficult to confidently assess due to 318 the mode of preservation. The dentition of Theriosuchus (Owen, 1879; Joffe, 1967; 319 Brinkmann, 1992; Martin et al., 2010) is substantially different in that it is 320 heterodont. No palatal elements are visible, and aspects of the anatomy of the 321 premaxilla, maxilla, nasals and external nares are difficult to discern due to dorsal 322 flattening into the matrix and mandible, and because of the absence of the distal 323 snout tip. The occipital region of the skull is also obscured by matrix and crushed, 324 granular bone fragments, which probably represent the anterior-most elements of 325 the axial skeleton.

326 There is a ventrolateral notch between the premaxilla and maxilla but, unlike 327 in Theriosuchus ibericus (Brinkmann, 1992) and Theriosuchus sympiestodon (Martin 328 et al., 2010), this is not occupied by an enlarged tooth. The paired nasals contribute 329 to the external nares via a sagittal anterior projection, as in Alligatorellus beaumonti, 330 Alligatorium meyeri, and Theriosuchus pusillus. Wellnhofer (1971) regarded this 331 feature as diagnostic of Alligatorellus. However, it may be a synapomorphy of all 332 atoposaurids: in other crocodyliforms with divided external nares, this division is 333 formed by a sagittal projection of the premaxillae, e.g., the metriorhynchid 334 Maledictosuchus (Parrilla-Bel et al., 2013), whereas the external nares are fully open 335 or only partially divided posteriorly in eusuchians (e.g., Delfino et al., 2008). A pair 
336 of small, slit-like antorbital fenestrae are present and are entirely enclosed by the

337 nasals, a feature absent in $A$. beaumonti, but present within all specimens of

338 Theriosuchus for which the snout is preserved; as such we consider this feature to

339 be locally diagnostic of $A$. bavaricus within non-Theriosuchus atoposaurids. The

340 dorsal surface of the nasals is sculpted by faint longitudinal crenulations, a feature

341 unique within Atoposauridae, but also present in the goniopholidid

342 Eutretauranosuchus delfsi (Smith et al., 2010; Pritchard et al., 2013). As such, this

343 feature is considered a local autapomorphy of $A$. bavaricus. Posterior to the external

344 nares, the lateral margins of the nasals are straight, contrasting with the concave

345 margins observed in $A$. beaumonti. The dorsolaterally facing orbits are large with

346 respect to the cranium, occupying about one third of the total cranial length and the

347 majority of the skull width. This is comparable to Atoposaurus oberndorferi but

348 distinct from $A$. beaumonti, in which the orbits occupy one quarter of the skull

349 length. The relatively large size of the orbits might represent retention of a

350 paedomorphic characteristic (Joffe, 1967). A large amount of secondary calcite

351 growth is present within the orbit, obscuring much of the internal cranial

352 morphology. The right lateral temporal fenestra is deep and arcuate in cross-

353 sectional morphology, but largely obscured as a result of the crushing of the skull. It

354 is separated from the orbit by a mediolaterally-oriented postorbital bar, which

355 descends steeply into the posterolateral internal margin of the orbit. The lateral

356 temporal fenestra is similar in size to the dorsally located supratemporal fenestra,

357 and is approximately a quarter of the size of the external opening of the orbit.

358 The frontals are mediolaterally concave, to a slightly greater degree than the

359 parietals, and become extremely thin at the orbital margin, lacking the elevated

360 orbital rims seen in Theriosuchus (Owen, 1879). Compared to the nasals, they are

361 relatively wide with respect to the frontals in $A$. beaumonti. The anterior frontal

362 ramus extends slightly beyond the anterior tip of the prefrontal, a feature which we

363 consider to be a local autapomorphy because of its absence in other atoposaurids,

364 but that is present in some other non-eusuchian neosuchians, including

365 Eutretauranosuchus delfsi (Pritchard et al., 2013) and Pholidosaurus purbeckensis

366 (Salisbury, 2002; Montefeltro et al., 2013). The anterior contacts between the 367 frontals, prefrontals and lacrimals are largely obscured, as is the overall morphology

368 of these pre-orbital elements. However, the majority of the anterior margin of the 369 orbits comprises a deep and thick wedge of bone that descends as a vertical sheet 370 into the orbit, forming a distinctive anterodorsal brow. The maxilla contributes 
371 extensively to the ventral margin of the orbit, with the contact between the maxilla

372 and the lacrimal becoming indiscernible more anteriorly as a result of the mode of

373 preservation. The jugal occupies half of the ventral margin of the orbit, posterior to

374 the maxilla. Palpebrals were either absent or are not preserved, but appear to be

375 present in the anterior orbit of Alligatorellus beaumonti.

376 Posterior to the orbits, the dorsal surface of the skull is mildly sculpted by 377 anisotropic and heterogeneously spaced pits that are similar to Alligatorellus

378 beaumonti, but are less prominent than those seen in Theriosuchus and 379 Alligatorium. In contrast, this surface is smooth and unsculpted in Atoposaurus 380 (Wellnhofer, 1971; JPT, pers. obs.). It is plausible that the heterogeneous degree of 381 cranial sculpting seen in atoposaurids including Alligatorellus and Montsecosuchus is 382 useful in distinguishing specimens at the species level. Between the supratemporal 383 fenestrae is a prominent mediolateral ridge defining the suture between the frontal 384 and parietal, a feature we consider diagnostic of $A$. bavaricus. The anterior parietal 385 is not sculpted where it contacts the frontals, unlike $A$. beaumonti where the whole 386 cranial table (excluding the frontals) is homogeneously sculpted with small circular 387 pits. The squamosal is homogeneously sculpted, as with the parietal, with a dorsally 388 convex dorsal surface and orthogonal lateral and posterior margins, differing from 389 Theriosuchus pusillus which has a smooth posterolateral process (Owen, 1879; JPT, 390 pers. obv.). The cranial table is mostly flat, as is the case in most other atoposaurids, 391 with the exception of the slightly domed structure that characterises 392 Montsecosuchus (Buscalioni and Sanz, 1990a), and possibly Atoposaurus. The 393 anterolateral portion of the squamosal is sharply pointed and curves 394 posteromedially around the supratemporal fenestra. Here, it is initially gently 395 arcuate, then becomes straight as it contacts the parasagittally-directed and 396 straight medial edge. This gives the squamosal an overall distorted rhombohedral 397 shape in dorsal aspect. The majority of the dorsomedial margin of the squamosal 398 contributes to the supratemporal fenestra, with the lateral portion obscuring most of 399 the ventrally-placed quadrate and quadratojugal. The posterolateral process of the 400 squamosal is greatly reduced compared to other atoposaurids, in which it generally 401 tapers to a point, and is therefore considered to be a local autapomorphy of $A$. 402 bavaricus, being similarly present in other basal neosuchians such as Amphicotylus 403 lucasii (Mook, 1942). In Alligatorellus beaumonti, there is no development of the 404 posterolateral process, the posterior edge instead being slightly anterolaterally 405 directed. Between the supratemporal fenestrae, the paired, rectangular parietals are 
406 as mediolaterally wide as the frontals between the orbits. The parietals contribute to

407 the posteromedial margin of the supratemporal fenestra, but the relationship with

408 the postorbitals is difficult to see due to post-mortem damage. However, the 409 postorbital bar is present and weakly developed, possessing a superficial furrow 410 connecting the orbit and the supratemporal fenestra. The frontal only contributes to 411 the supratemporal fenestra at its anteromedial edge. Here, the frontal and parietal 412 form a lateral wedge, which thins laterally into the postorbital bar. The posterior 413 portion of the dorsal surface of the parietal is smooth, a feature otherwise only 414 found in Atoposaurus, although in that taxon the skull is entirely unsculpted 415 (Wellnhofer, 1971; JPT, pers. obv.); as such, we consider this heterogeneous pattern 416 of cranial sculpting to be autapomorphic for $A$. bavaricus. The lateral and ventral 417 surfaces of the skull are largely obscured by the displaced and crushed mandible, 418 and the preserved orientation of the skeleton.

419 The mandible is not visible ventral or anterior to the orbit, and is largely 420 obscured posteriorly. It has been slightly dorsally displaced into the ventrolateral 421 portion of the right-lateral face of the skull. The mandible broadens posteriorly both 422 mediolaterally and dorsoventrally, developing a lateral shelf as it flares out beneath 423 the lateral temporal fenestra, possibly at the position at which the mandibular 424 fenestra would have been situated. The ventral margin of the mandible curves 425 medially and substantially thins mediolaterally at its posterior extremity, where it 426 forms an acute and recurved process, the posterior margin of which is gently 427 concave and slightly set back from the posterior edge of the cranial table.

428 Axial skeleton: One of the most striking features of atoposaurids is that the 429 tail length is greater than the length of the torso, and comprises approximately one430 half of the total length of the skeleton. In Alligatorellus bavaricus there are seven 431 cervical (including the axis and atlas) and fifteen dorsal vertebrae (note that 432 Wellnhofer (1971) observed only seventeen presacral vertebrae, using osteoderm 433 count as a proxy). These vertebrae are mostly indistinguishable from one another, 434 but their presence is estimated based on their associated dorsal paravertebral 435 osteoderms which, along with the poor preservation of the trunk region, largely 436 obscure the morphology of the vertebral column. As noted by Wellnhofer (1971), 437 three sacral vertebrae seem to be present, but their preservation means that this 438 cannot be determined with any certainty, with all elements crushed beyond 439 distinction. If correctly determined, sacral count might be a distinguishing feature 440 between $A$. bavaricus and $A$. beaumonti, with the latter only having two sacral 
441 vertebrae, but variation in sacral count is difficult to discern in atoposaurids due to 442 poor preservation of the axial skeleton in specimens of Alligatorellus. There are 443 around forty caudal vertebrae, although the precise number is difficult to determine, 444 with the distal-most two or three absent, as indicated by impressions. Much of the 445 caudal vertebral series is variably covered in matrix and fixing glue, obscuring most 446 of the morphological detail and intervertebral articulations. In the central caudal 447 series, a melange composed of dorsal and ventral paravertebral osteoderms 448 obscures much of the anatomical detail. Only the first four caudal vertebrae can be 449 used to observe any of the anatomy from a right-lateral perspective. It is unknown 450 whether the vertebrae were procoelous, as in Theriosuchus and eusuchians (e.g., Pol 451 et al., 2009), or amphicoelous.

452 The dorsal osteoderms occur in a biserial row from the anterior-most cervical 453 vertebrae to about the mid-point of the caudal series, a feature that characterises all 454 unambiguous atoposaurids, with the exception of Atoposaurus, and that is also 455 absent in the putative atoposaurid Karatausuchus (Efimov, 1976; Storrs and Efimov, 456 2000). The osteoderms of $A$. bavaricus are imbricated along their entire length, and 457 there is no 'peg and socket' articulation as described in two scutes assigned to 458 Theriosuchus pusillus (Owen, 1879; Schwarz-Wings et al., 2011) and in Theriosuchus 459 guimarotae (Schwarz and Salisbury, 2005). The osteoderms of $A$. bavaricus are 460 rounded, and the lateral edges are predominantly convex, with one or two being 461 marginally concave. There is a central longitudinal ridge on the dorsal surface of 462 osteoderms of $A$. bavaricus, similar to some of the caudal osteoderms in 463 Theriosuchus, but contrasting with Alligatorium meyeri and other atoposaurids. The 464 degree of sculpting on the osteoderm dorsal surfaces increases posteriorly, as does 465 the prominence of the longitudinal keel which shifts to a slightly medial position 466 from an initially more central position, unlike Alligatorellus beaumonti in which it is 467 consistently laterally placed as a distinct shelf. The lateral and medial edges of the 468 osteoderms are smooth and either straight or convex, and the straight anterior and 469 posterior margins are parallel. The morphology of the ventral osteoderm series is 470 very similar, where visible, but with more prominent longitudinal ridges in the more 471 posterior elements. There is no visible morphological heterogeneity in the nuchal 472 and sacral osteoderms, contrasting with Alligatorellus beaumonti in which this 473 feature is highly distinctive. It is unknown whether the ventral series are paired or 474 not in $A$. bavaricus, as the ventral portion of the skeleton is mostly unobservable. 
Other minor axial elements are partially visible beside the osteoderms. Two thoracic ribs are preserved embedded within the trunk melange. They are gently arcuate in their overall morphology, and not preserved in situ. There are several other rib elements more anterior to these and just ventral to the anterior-most osteoderms, but they are largely obscured by the overlying matrix and axial elements. Three posteroventrally directed chevrons are in situ with their proximal caudal vertebrae, positioned just posterior to the only visible three-dimensionally preserved vertebrae.

Pectoral girdle: Only the right scapula is preserved, and is fragmented at both ends, including both the glenoid fossa and coracoidal contact. It is bow shaped, with a distinct dorsoventral contraction and mediolateral thickening into a compressed cylindroid at mid-length. The dorsal surface becomes thin and sharp anteriorly, culminating in a broad and deep, basin-like medial depression, contrasting with Montsecosuchus depereti in which the entire element is flat (Buscalioni and Sanz, 1990a). The proximodorsal edge overhangs this depression, a feature not observed in other atoposaurids, and is considered to be a diagnostic feature of $A$. bavaricus. Posteriorly, the scapula flares out in a similar fashion to the anterior blade, but the distal portion is mostly absent, so the complete morphology is unknown. A posteroventral process projects out from the posterior blade, twisting from the ventral surface into a short, thickened rod.

Forelimbs: The right forelimb is nearly complete, with an articulated humerus, radius and ulna, but the manus is crushed. The proximal third of the humerus is also crushed, with the external cortices of the exposed shaft removed, revealing the internal bone. The humerus expands slightly proximally, and the shaft is straight and broader mediolaterally than anteroposteriorly. The morphology of the deltopectoral crest cannot be determined. The radial condyle is broad and directed anteriorly. The distal articular surface of the humerus is strongly rugose, and oriented at $40^{\circ}$ to the long axis of the shaft. The shaft is relatively straight, similar to more advanced neosuchians such as Shamosuchus (Pol et al., 2009). The anterior intercondylar

504 groove is not visible, but the supracondylar fossa forms a deep posterior furrow, 505 terminating a short distance up the shaft, and is bound medially by the relatively 506 weaker ulnar condyle, the morphology of which is mostly obscured. The external 507 surfaces of the condylar heads are smooth. The humerus is slightly shorter than that 508 of $A$. beaumonti, but the radius is proportionally longer. The stylopod to zeugopod 
509 ratio in both limbs is proportionally lower than in all other atoposaurids, a feature 510 that we consider diagnostic of $A$. bavaricus.

511 The radius is slightly longer than the more robust ulna, the two resting against 512 each other without twisting sharply; as such the respective proximal and distal 513 articular surfaces have long axes in the same orientation. The radius is gently 514 longitudinally arcuate in its proximal third, conforming to the gentle curvature of the 515 distal ulnar shaft. The radial head is mediolaterally expanded, and is about two516 thirds the size of the ulnar head it rests against. The ulnar head is damaged, and the 517 radial head and the associated humeral condyle actually appear quite mismatched 518 in size, suggesting a large volume of cartilage or muscle attachment at this joint, 519 also emphasised by the heavily rugose articular surface. The lateral part of the 520 radial shaft thins to about $70 \%$ of its width and becomes ridge-like at around two521 thirds of its length. The ulnar shaft is equidimensional through its entire length, and 522 finishes with a triangular-shaped distal articular surface. The carpus cannot be fully 523 observed.

$524 \quad$ Little of the left forelimb is preserved: the distal humerus is crushed, with the 525 proximal ulna and entire radius missing, preserved only as impressions. However, 526 aspects of the morphology of the carpus can be observed. The radiale is long and 527 slender, with expanded proximal and distal ends, much like $A$. beaumonti in which 528 the elements are well-preserved in the holotype. The ulnare is slightly shorter, with a 529 stronger mediolateral compression of the shaft, and overall more gracile 530 morphology. In $A$. beaumonti, the ulnare has a proximal groove on the lateral 531 surface, terminating at $80 \%$ of the length of the element, but whether this is present 532 in A. bavaricus cannot be determined. However, the ulnare in $A$. bavaricus is not 533 'hatchet shaped' as in A. beaumonti or the specimen assigned to Alligatorellus sp. 534 by Schwarz-Wings et al. (2011). Furthermore, the radiale in $A$. beaumonti is larger 535 than the ulnare, distinguishing the two species of Alligatorellus. All additional carpal 536 elements in $A$. bavaricus are crushed to the point where their morphology cannot be 537 meaningfully observed. The entire manus is bent backwards, indicated by its 538 impression and in a similar manner to the pedal orientations. All of the elements are 539 highly distorted and crushed, with only moderate lateral compression indicated by 540 the slight crushing of the more gracile elements.

541 Pelvic girdle: Only fragments of the pelvic girdle are preserved. The ilium 542 forms an elongated S-shape in dorsal view, and is thickened anteriorly. Much of the 543 morphology is obscured by the orientation of the specimen on the rock slab, but the 
544 postacetabular process appears to be fenestrated at its tip (although this might be a 545 post-mortem artefact), greatly thickened, and leads into a deep and broad 546 acetabulum. An element just below this on the slab is one of the pubes. Much of the 547 morphology is again obscured by the orientation in which it is embedded in the 548 matrix. The proximal head is expanded into a broad wedge-shape and twists slightly 549 to become oblique to the stouter distal end, which is more circular in cross section. 550 The proximal portion of the shaft is transversely flattened and sub-elliptical in cross551 section, and has a strongly rugose surface, partially obscured by an overlying 552 displaced rib. There is a fan-shaped structure situated anterior to the ilium, which

553 we interpret as a fragment of the anteriorly displaced ischium. The distal end is thin 554 and gently convex, with a slightly crenulated distal extremity. Gentle striations from 555 the distal end are directed towards the transversely thickened shaft, which increases 556 in breadth more proximally on the dorsal margin and has a more slender ventral 557 margin. The proximal end is hidden underneath the skeleton so that the remaining 558 morphology cannot be observed.

559 Hindlimbs: Overall, the hindlimbs are about 1.4 times the length of the 560 forelimbs. The right hindlimb is mostly complete with a laterally flattened tarsus and 561 pes. The femur is missing from the left hindlimb (although it is possibly hidden 562 underneath the skeleton), and the tibia and fibula are both crushed. The left pes is 563 well-preserved, with partially crushed tarsal and pedal elements. The femur is the 564 most robust limb bone of the skeleton, and is morphologically similar to the ulna, 565 being gently sigmoidal down the length of the shaft. The femoral head is moderately 566 expanded and equidimensional to the distal end of the femur. The femoral head 567 grades smoothly into the posteriorly placed fourth trochanter, which is weakly 568 developed, ridge-like, and distally thickened, terminating at one-sixth of the length 569 from the proximal end. Adjacent to this, on the lateral surface, there is an 570 accompanying groove for attachment of the femoral-pelvic musculature. The distal 571 end of the right femur is damaged and fractured, and the distal condylar 572 morphology cannot therefore be determined.

573 The left tibia and fibula are mostly concealed within the slab and underneath 574 other bones, and only the straight shafts are exposed. The lateral surfaces of both 575 elements from the right hindlimb are fully exposed, and demonstrate that they are 576 equal in length to the femur. Both ends of the tibial shaft are anteroposteriorly 577 compressed, with the distal end slightly more so. The proximal portion of the tibia is 578 slightly posteriorly deflected, but to a lesser degree than in Alligatorellus beaumonti. 
579 The tibial shaft becomes slightly anteroposteriorly expanded at mid-length. Distally, 580 the lateral margin of the tibia thins anteroposteriorly, culminating in a sharp ridge at 581 the distal end, and resulting in a triangular cross-section. The proximal half of the 582 fibula is gently twisted to accommodate the mid-tibial expansion, and articulates 583 with the posterior face of the proximal head of the tibia. As a result of the fully 584 articulated nature of the tibia and fibula, the morphology of the proximal and distal 585 articular surfaces is obscured. Furthermore, the distal end of the fibula is damaged. 586 In lateral view, the fibula is much more slender than the tibia, and has a more 587 circular cross section than the elliptical to triangular tibia. The astragalus is not 588 visible in either hindlimb. The calcaneum is present, but is obscured by matrix and 589 glue.

On the right hindlimb, metatarsals I-III and part of metatarsal IV are preserved, as well as a poorly preserved, vestigial fifth metatarsal that is less than one-third the length of the other four metatarsals. Their long axes are parallel to one another, with the proximal and distal ends resting against each other. The nature of the distal articulations is obscured. The left pes is preserved in an oblique view, and provides a better perspective of the metatarsal morphology, although metatarsal $\mathrm{V}$ is not visible. The tarsal phalangeal formula, as stated by Wellnhofer (1971), is 2-34-4-(1). The metatarsals are long, gracile, and transversely expanded at their proximal ends with an overall similar morphology to one another. Their distal ends have been slightly anteroposteriorly compressed, and the straight shafts all have an elliptical cross-section. On the left pes, the proximal tip of metatarsal I is obscured beneath metatarsals II-IV but, where visible, the metatarsal is anteroposteriorly compressed, and twists anteromedially towards its distal end, at which point it thickens and broadens into a sub-oval cross section. The distal articular surface of metatarsal $I$ is only partially visible; this rugose surface curves medially to occupy the distal-most edge of the medial surface. Metatarsal II is slightly longer than metatarsal I, with a mediolaterally compressed proximal end, and a ventral surface that forms a thin ridge. Metatarsal II gradually thickens distally, and the shaft twists in a similar manner to metatarsal I, but instead the ventromedial edge becomes more prominent as a ridge, bounding the medial edge of a small distal depression on the ventral surface. The distal end of metatarsal II is convex, and the articular

612 shaft appearing to be as long as metatarsal II but thickened to a lesser degree 613 distally. Metatarsal III is slightly more gracile than the others. The sharpness of the 
614 proximoventral ridge is also less apparent in metatarsal III. Metatarsal IV is mostly

615 obscured, but has a straighter, less twisted shaft that is more continuously oval in

616 cross-sectional morphology than the metatarsals.

617 Additional material previously referred to Alligatorellus

618

619

620

621

622

623

624

625

626

627

628

629

630

631

632

633

634

635

636

637

638

639

640

641

642

643

644

645
Atoposauridae indet.

Alligatorellus sp. Schwarz-Wings et al., 2011

Specimen: MfN MB. R. 4317.1-12, a partial disarticulated skeleton.

Locality and horizon: Kelheim, Bavaria, Germany; early Tithonian, Hybonotum Zone, Rueppelianus Subzone (Schwarz-Wings et al., 2011).

Preservation: Disarticulated axial and appendicular elements adjacent to a single row of paravertebral osteoderms. Some limb elements have been prepared out of the matrix.

Comments: An additional specimen from Bavaria was recently assigned to Alligatorellus sp. by Schwarz-Wings et al. (2011). This is a substantially larger individual than the four known specimens comprising $A$. beaumonti and $A$. bavaricus, and is represented by a disarticulated, partial postcranial skeleton. With the revised diagnosis presented above for Alligatorellus, the only comparable diagnostic material is the osteoderms, which differ in morphology to those of $A$. beaumonti and A. bavaricus. Distinguishing features present in MfN MB. R. 4317.112 include: (1) dorsal osteoderms are square-shaped, rather than rectangular, with a possible anterior articular process (similar to the 'peg and socket' morphology seen in some specimens of Theriosuchus and goniopholidids); (2) dorsal osteoderms are distinctly asymmetrical about their long-axis; (3) ventral osteoderms bear a series of nutrient foramina, as well as an anteroposteriorly oriented ridge along their anterior portions (although note that this aspect of the osteoderms is not visible in any specimen of Alligatorellus beaumonti or A. bavaricus); and (4) caudal osteoderms are often laterally serrated, grading from a narrow to elongated elliptical shape. Several of these features regarding osteoderm morphology may be diagnostic within Atoposauridae. An additional difference is the more laterally than medially expanded proximal end of the radiale, with a proximodistally oriented crest extending along the anterior surface of the shaft. This, together with the outlined differences in osteoderm morphology indicates, that MfN MB. R. 4317.1-12 may represent a 
646 distinct atoposaurid taxon, or another species of neosuchian outside of 647 Atoposauridae.

648 Based on the revised diagnosis for Alligatorellus presented in this study, and 649 the notable differences in preserved osteoderm morphology, it is questionable 650 whether the specimen described by Schwarz-Wings et al. (2011) can be assigned to 651 Alligatorellus. Its initial referral to this genus was based on several lines of evidence, 652 including the longitudinally elliptical shape of the caudal osteoderms, a feature 653 otherwise only seen in the distal-most caudal osteoderms of Alligatorellus 654 beaumonti, although they are more rectangular in the French taxon. However, the 655 morphology of the osteoderms of MfN MB. R. 4317.1-12 is similar to the dorsal 656 osteoderms of Montsecosuchus depereti, including the presence of a continuous, 657 medially-positioned keel along the external surface (Buscalioni and Sanz, 1990a; JPT, 658 pers. obs.), but Montsecosuchus does not preserve any osteoderms of similar size or 659 morphology to the imbricated series preserved in MfN MB. R. 4317.1-12. The 660 imbrication of these dorsal osteoderms cannot be used to assign MfN MB. R. 4317.166112 to Alligatorellus, as this is a feature also present in Theriosuchus pusillus and 662 Alligatorium, the putative atoposaurid Brillanceausuchus, and other neosuchians 663 including Pachycheilosuchus (Rogers, 2003; JPT, pers. obs.). The higher degree of 664 sculpting of the osteoderms was regarded as ontogenetic variation by Schwarz665 Wings et al. (2011), but all other specimens of Alligatorellus also appear to represent 666 mature individuals. Therefore, the greater degree of sculpting observed in the 667 osteoderms of MfN MB. R. 4317.1-12 may represent a taxonomic difference. The 668 position of the dorsal keel on these osteoderms, and the lack of symmetry in their 669 outlines in dorsal aspect also represent differences between the osteoderms of MfN 670 MB. R. 4317.1-12 and those observed in other specimens assigned to Alligatorellus. 671 Additionally, the limb ratios presented in Schwarz-Wings et al. (2011, p. 203, table 2)

672 imply that this specimen is allometrically quite distinct from Alligatorellus, and 673 perhaps more closely related to Alligatorium. For now, we consider MfN MB. R. 674 4317.1-12 to be an indeterminate atoposaurid pending its inclusion in $a$ 675 comprehensive species-level phylogenetic analysis of Atoposauridae (in 676 preparation).

\section{Discussion}

678 Osteoderm morphology in atoposaurid systematics 
679 The morphology of the parasagittally-arranged postcranial osteoderms of 680 atoposaurids has not previously been regarded as an important characteristic in 681 atoposaurid taxonomy, generally due to their relatively rare preservation in situ 682 (e.g., Buscalioni and Sanz 1990a; Michard et al., 1990; Wu et al., 1996). The 683 exception to this is a study of western European specimens by Schwarz-Wings et al. 684 (2011). However, as noted here for specimens referred to Alligatorellus, subtle 685 differences in osteoderm morphologies, particularly the extent, position, and 686 continuity of the longitudinal keels on the dorsal surfaces, can prove to be 687 diagnostic at species level.

688 The pattern of ornamentation on the osteoderms of atoposaurid taxa, as with 689 other osteoderm-bearing crocodylomorphs (Vickaryous and Hall, 2008), is similar to 690 that seen in dermatocranial ornamentation, particularly with respect to the dorsal 691 surface of the skull table. Exceptions to this are Atoposaurus and the putative 692 atoposaurid Karatausuchus, in which there is no evidence of cranial sculpting, and 693 no evidence of preserved osteoderms (Wellnhofer, 1971). Furthermore, the general 694 distribution of osteoderms in Alligatorellus is similar to that in basal 695 crocodylomorphs such as protosuchians, sphenosuchians and the enigmatic taxon 696 Hoplosuchus kayi (Gilmore, 1926; JPT, pers. obs.), which have biserial rows of 697 imbricated, rectangular dorsal osteoderms that might have served in a more 698 functional support role than that proposed for atoposaurids (Clark and Sues 2002; 699 Pol et al., 2004). There remains the possibility that osteoderm morphology varies 700 intraspecifically, with multiple morphotypes represented within a population, as is 701 the case in some other archosaurs (e.g., ankylosaurs [Burns, 2008]). However, 702 sample sizes are currently too small to ascertain if this might be the case for 703 atoposaurids. Nevertheless, unequivocal intrageneric differences in osteoderm 704 morphology are observed between Alligatorium and Theriosuchus (e.g., Owen, 1879; 705 Wellnhofer, 1971; Wu et al., 1996), prompting consideration of its utility for 706 systematic placement of Alligatorellus.

707 Establishing the positional homology of osteoderms is important for 708 evaluating taxonomic status in many tetrapod groups, including crocodylians (Ross 709 and Meyer, 1983), aetosaurians (Parker, 2007; Parker and Martz, 2010), and 710 chronosuchians (Buchwitz et al., 2012). This is difficult in the case of less complete 711 or disarticulated specimens, such as that described by Schwarz-Wings et al. (2011) 712 as Alligatorellus sp., comprising articulated and disarticulated elements which they 713 considered to represent a single individual with heterogeneous osteoderm 
714 morphology. In Alligatorellus, both the positional homology and differences in

715 morphology in the discrete axial regions are diagnostic at species level. There are

716 four regions: cervical (or nuchal), dorsal, sacral, and caudal. These regions typically

717 comprise continuous rows of anteroposteriorly arranged (paramedian or

718 paravertebral) osteoderms. On the basis of osteoderm morphology and

719 configuration, Alligatorellus differs from Theriosuchus pusillus and advanced

720 eusuchians (e.g. Leidyosuchus) which have the ventral body encased within an

721 articulating (but not overlapping or imbricating) shield of parasagittal rows of

722 singular osteoderms (Owen, 1879; Brochu, 1997). It also differs from Alligatorium, in

723 which osteoderms bear no dorsal keel, and from Montsecosuchus which has two to

724 three rows of non-imbricating, and longitudinally oval dorsal osteoderms. Below, we

725 discuss the three different morphotype series found in specimens ascribed to

726 Alligatorellus.

\section{A. bavaricus morphotype}

728 The dorsal keel in osteoderms of $A$. bavaricus is in a more medial position 729 nuchally, gradually migrating laterally along the dorsal series before becoming 730 medially placed in the sacral and caudal series (Fig. 8A). Throughout this gradation, 731 individual osteoderms are similarly robust, but adopt an increasingly more sub732 rectangular to elliptical morphology posteriorly. Whereas they imbricate in the dorsal 733 series, this change in shape leads to them abutting one another longitudinally, with 734 no overlap. The longitudinal keel always occupies the entire length of the dorsal 735 surface, and becomes more prominent posteriorly. There is a caudal ventral series of 736 secondary osteoderms, but these are few in number and do not extend beyond the 737 anterior half of the tail. This is similar to the condition in Montsecosuchus depereti

738 (Buscalioni and Sanz, 1990a), but contrasts with Theriosuchus, in which they extend

739 to the end of the caudal series. In contrast to $A$. beaumonti, the dorsal keel observed

740 in sacral and anterior caudal osteoderms of $A$. bavaricus never develops an incipient 741 posterior projection. It is likely that the 'accessory osteoderms' of Alligatorellus

742 bavaricus described by Wellnhofer (1971) are the result of incomplete osteoderm 743 development: they appear to be mostly comprised of the longitudinal keel, which

744 forms as part of the earliest phase of osteoderm development Vickaryous and Hall, 745 2008).

746 A. beaumonti morphotype 
The biserially arranged osteoderms of $A$. beaumonti form a continuous dorsal shield, similar to Theriosuchus pusillus and other atoposaurids (Fig. 3). Their longitudinally imbricating arrangement is comparable to that of extant alligatoroid species such as Caiman crocodilus and Alligator mississippiensis (Burn et al., 2013), but with fewer paramedian dorsal series. The extent of the caudal ventral series is much greater than in $A$. bavaricus, forming a complete dermal coating. The distalmost osteoderms are small, seemingly under-developed, sculpted elements. In the caudal series, the longitudinal ridges are pronounced, longitudinally extensive, and medially placed, similar to $A$. bavaricus. The more sacrally placed caudal elements have less pronounced keels than $A$. bavaricus. They also become smaller and more ovate, with the ridges gradually almost disappearing, and only occupying the posterior portion of each element, whereas sculpting remains the same. This skewing of the keels is most pronounced in the dorsal and sacral osteoderms, where they form rounded protrusions on the dorsal side and become laterally displaced on the ventral series. This unusual shift is particularly evident in the dorsal series, where the lateral keel becomes more prominent and more anteroposteriorly extensive, forming a distinct step from the main body of each osteoderm (Fig. 8B).

764 The ventral and dorsal morphology is quite similar, with the ventral keels almost seeming to diverge ventrally with each accompanying rib. The sacral and anteriormost caudal osteoderms develop an incipient lateral projection, almost appearing to diverge into two individual elements medial to this. The ventral series either terminates around the position of the third dorsal rib, or is not preserved anteriorly from this point. The dorsal series adopts a heterogeneous range of morphologies, with some elements reducing to around one-sixth the size of the other osteoderms more nuchally, and with all losing the presence of the keel. This contrasts with Alligatorium meyeri and Theriosuchus pusillus, where they are morphologically continuous.

The deeper sculpting present in this specimen was ascribed to ontogenetic variation by Schwarz-Wings et al. (2011), based on its larger size compared to other specimens of Alligatorellus (Fig. 8C). Maturity of the type specimens of both species

778 of Alligatorellus is discussed above, as are differences in osteoderm morphology,

779 suggesting that this specimen represents a distinct taxon from Alligatorellus. These 780 differences include the more medial position of the keel in MfN MB. R. 4317.1-12, 
781 and the lateral deflection of the body of the osteoderms adjacent to this. The keel is

782 also not as longitudinally continuous in MfN MB. R. 4317.1-12 as it is in A. beaumonti

783 and $A$. bavaricus. Additionally, the lateral edge is serrated, and there are unsculpted

784 areas on the dorsal surface. Moreover, they are less robust overall than the other

785 specimens of Alligatorellus, in spite of their greater size, and overall appear similar

786 to the osteoderm ascribed to Theriosuchus sp. by Wu et al. (1996).

787 The taxonomic validity of Atoposaurus and Alligatorium

$788 \quad$ Alligatorellus beaumonti coexisted with Atoposaurus jourdani and Alligatorium

789 meyeri in eastern France, while Alligatorellus bavaricus lived alongside Atoposaurus

790 oberndorferi and possibly Alligatorium franconicum and Alligatorium paintenense in

791 southeastern Germany (Wellnhofer, 1971; Figs. 1, 2). This high diversity of

792 atoposaurids in the Late Jurassic of Germany and France, combined with potential

793 juvenile features in Atoposaurus, has led some to suggest that Atoposaurus might in

794 fact represent a juvenile specimen of one of the other sympatric atoposaurid species

795 (Buscalioni and Sanz, 1988). Furthermore, Benton and Clark (1988) suggested that

796 Atoposaurus, Alligatorellus and Alligatorium might represent a single growth series.

797 Ontogenetic allometric variation has received considerable attention in extant

798 crocodylians, particularly in population-level studies (e.g., Dodson, 1975). Through

799 crocodylian ontogeny, several allometric relationships have been recognised in

800 different taxa: (1) the skull lengthens, and becomes more dorsoventrally flattened

801 and laterally compressed in Caiman (Monteiro and Soares, 1997; Monteiro et al.,

802 1997); (2) the skull lengthens and widens in Alligator sinensis (Wu et al., 2006),

803 Crocodylus moreletii (Platt et al., 2009) and Crocodylus siamensis (Chentanez et al.,

804 1983), as does the snout in Alligator sinensis; (3) reduction in relative orbit size to

805 the skull occurs in Crocodylus acutus, Gavialis gangeticus, Mecistops cataphractus

806 and Tomistoma schlegelii (Piras et al., 2010); and (4) the orbit, snout and skull shape

807 changes through ontogeny in Caiman latirostris (Verdade, 2000). However, as

808 Verdade (2000) noted, many of these allometric factors covary with both size and

809 ontogenetic stage, and therefore it is often difficult to interpolate from these

810 allometric relationships to determine an ontogenic stage in fossil taxa.

811 To test the hypothesis that Alligatorellus, Alligatorium and Atoposaurus

812 represent a single ontogentic series, or that Atoposaurus is a juvenile of at least one

813 of the other taxa, we plotted a number of anatomical measurements (skull width,

814 snout length, and orbit length) for each of the species against skull length, and also 
815 carried out a covariance-based Principal Components Analysis (PCA) in R ( 816 Development Core Team, 2014) (Fig. 9).

$817 \quad$ An increase in skull width and snout length relative to skull length is seen in 818 both the French and German atoposaurid groups, although this is much more 819 pronounced in the German specimens as a result of the longirostrine form of 820 Alligatorium franconicum (figs. 9A, B). However, this trend is not entirely linear, with 821 Alligatorellus beaumonti having a distinctly longer, but almost equally wide, skull 822 relative to Atoposaurus jourdani. A similar pattern is recorded for orbit length 823 relative to skull length, although this trend is considerably less pronounced in the 824 German taxa, and there is little difference between Atoposaurus jourdani and 825 Alligatorellus beaumonti, despite an almost doubling of skull length (Fig. 9C). If 826 Atoposaurus, Alligatorellus, and Alligatorium were part of the same growth series, 827 we would expect a consistent relationship between the two geographic groups in 828 each of these aspects, a pattern not produced here.

829 Our PCA of six primary measurements (skull length, skull width, orbit length, 830 ulna length, femur length and tibia length) shows a distinct pattern, with the three 831 genera separated in morphospace, especially along PC-1 (Fig. 9D). Furthermore, 832 neither the French or German specimens show equivalent distributions to each 833 other, which might be expected if each basin records the same taxon along one 834 growth series. The two Atoposaurus species are distinguished by the PC-1 $(94.1 \%$ 835 variance). Alligatorellus species are weakly distinguished from each other by PC-2 836 (2.8\% variance), but show almost no variation in PC-1. Whereas the two Alligatorium 837 species are strongly distinguished from each other on PC-2, they are closely united 838 by PC-1 (Fig 9D). As such, we find no convincing uni-directional evidence that 839 Atoposaurus, Alligatorellus, and Alligatorium form a single growth series of one 840 species. Although we cannot fully preclude the possibility that Atoposaurus 841 represents an immature specimen of either Alligatorellus or Alligatorium, below we 842 discuss other anatomical features that support its taxonomic validity.

843 Atoposaurus is unique among all unequivocal atoposaurids in lacking 844 osteodermal armour. Schwarz-Wings et al. (2011) suggested that this might merely 845 be a taphonomic artefact; however, preservational selectivity of this nature seems 846 unlikely given that there is no clear reason why similarly ossified parts of the 847 skeleton would undergo differential preservation. Combined with its diminutive size, 848 the absence of any cranial sculpting, and lack of calcified palpebrals, the absence of 849 osteoderms might suggest a juvenile status. Furthermore, Atoposaurus looks 
850 superficially similar to a juvenile specimen of the alligatoroid Diplocynodon from

851 Messel (Eocene; Delfino and Sánchez-Villagra, 2010, Fig. 3A), in terms of the 852 relatively long caudal vertebral series, large orbits, lack of ossification of the dermal 853 armour, and proportionally short skull. As such, Atoposaurus superficially takes on 854 the appearance of more advanced eusuchians, while retaining paedomorphic 855 characteristics (e.g., the proportionally large orbits). In crocodylians, the initiation of 856 osteoderm ossification is usually substantially delayed relative to skeletal 857 ossification (Vickaryous and Hall, 2008), so it is difficult to infer a more accurate 858 ontogenetic age for Atoposaurus specimens based solely on a lack of osteoderms. 859 However, there are additional morphological aspects that demonstrate that 860 Atoposaurus might not be a juvenile.

861 Similar to most other atoposaurids, Atoposaurus has a relatively short, low, 862 acute, triangular skull. However, as with some theropod dinosaurs, the extant 863 crocodylian Osteolaemus, and perhaps even the alligatoroid Alligator, shortening of 864 the rostral region may be a paedomorphic feature, with the morphology similar to 865 juveniles and sub-adult specimens of Melanosuchus (the black caiman) (Foth, 2013). 866 A platyrostral skull is also known in basal eusuchians such as Iharkatosuchus 867 maxakii (Osi et al., 2007), and is distinct from the majority of contemporaneous 868 crocodylomorphs, including goniopholidids and thalattosuchians. Heterochrony in 869 crocodylomorphs may be directly related to body size or diet, as atoposaurid species 870 and Osteolaemus are relatively small forms that occupy distinctive ecologies. 871 However, patterns of heterochrony, particularly relating to paedomorphosis, in 872 'dwarfed' species are currently poorly understood in crocodylomorphs, but could be 873 responsible, at least in part, for the lack of osteoderm ossification in Atoposaurus.

874 The degree of suturing between the vertebral centrum and neural arch 875 provides ontogenetic information (Mook, 1933; Brochu, 1996). Closure of cervical 876 sutures is a consistent indicator of morphological maturity, and is known in basal 877 crocodylomorphs (e.g. thalattosuchians; Delfino and Dal Sasso, 2006) and advanced 878 eusuchians (Brochu, 1996). In Atoposaurus jourdani, the neural arches are fused to 879 the centra (MNHN 15680; JPT, pers. obv.), which implies that this specimen 880 represents a more mature growth stage despite the size of the individual. 881 Furthermore, it is interesting to note that other putative atoposaurids of diminutive 882 size, such as the $160 \mathrm{~mm}$ long Karatausuchus (Efimov, 1976), also lack osteoderms, 883 suggesting that osteoderm development might be positively correlated with body 
884 size in atoposaurids. We therefore suggest that Atoposaurus represents an extreme 885 case of dwarfism.

886 Alligatorium is currently composed of three species: A. meyeri from Cerin, 887 France (Vidal, 1915), and A. franconicum (Ammon, 1906) and A. paintenense (Kuhn, 888 1961) from Painten, central Bavaria, Germany. However, based on the figures and 889 descriptions provided by Wellnhofer (1971), A. franconicum (an articulated hindlimb 890 and pelvic girdle) cannot be distinguished from $A$. paintenense (a near-complete, 891 articulated skeleton), aside from slight differences in femur-to-tibia length 892 proportions. Given that both specimens are from the same locality, we tentatively 893 conclude that they do not represent distinct species, and regard $A$. paintenense 894 (Kuhn, 1961) as synonymous with $A$. franconicum (Ammon, 1906), pending the 895 relocation of the type material and/or discovery of new material. The type specimen 896 of $A$. paintenense is clearly distinct from $A$. meyeri and both species of Alligatorellus, 897 based on its more longirostrine snout, and dorsal osteoderms which each possess a 898 longitudinal keel and an anterolateral hook (Wellnhofer, 1971). Alligatorium meyeri 899 can be distinguished from Alligatorellus based on the absence of a longitudinal keel 900 on all osteoderms in the latter taxon, as well as disparity in the cranial sculpting 901 between the two taxa. As well as differing from Alligatorellus and Alligatorium in 902 terms of the absence of osteoderms, Atoposaurus can also be distinguished via 903 caudal osteoderm counts, with ten less caudal vertebrae in the latter taxon (the 904 number is unknown for Alligatorium). A higher number of caudal vertebrae in

905 Atoposaurus is additional evidence that this taxon is not an immature individual of 906 at least Alligatorellus, given that we would not expect an individual to lose vertebrae 907 with increasing maturity. In summary, we retain Alligatorellus, Alligatorium and 908 Atoposaurus as distinct atoposaurid genera, with each genus comprising a valid 909 French and German species.

\section{European Atoposaurid Diversity}

911 The Late Jurassic-Early Cretaceous of Europe records high atoposaurid 912 diversity, comprising the multispecific genera Alligatorellus, Alligatorium, 913 Atoposaurus and Theriosuchus, as well as Montsecosuchus depereti (Gervais, 1871; 914 Owen, 1879; Wellnhofer, 1971; Buscalioni and Sanz, 1990a; Brinkmann, 1992; 915 Schwarz and Salisbury, 2005). Currently valid European species of Theriosuchus 916 include: T. guimarotae from the Kimmeridgian of Portugal (Schwarz and Salisbury, 
917 2005); T. pusillus from the Berriasian of England (Owen, 1879; Salisbury, 2002); T.

918 ibericus from the Barremian of Spain (Brinkmann, 1989, 1992); and T. sympiestodon

919 from the Maastrichtian of Romania (Martin et al., 2010; 2014). However, support for

920 the monophyly of these species of Theriosuchus has yet to be adequately evaluated.

921 Such evaluation is particularly required in view of the spatiotemporal distribution of

922 the genus as currently understood, which spans some 90 million years and includes

923 a putative Asian occurrence (T. grandinaris; Lauprasert et al., 2011).

924 Along with these relatively well-known species, there is a host of European

925 material ascribed to Theriosuchus sp. from: the Kimmeridgian of northwest Germany

926 (Thies et al., 1997; Karl et al., 2006); the Berriasian of Scandinavia (Schwarz-Wings 927 et al., 2009); the Berriasian of Charente, France (Pouech, 2006); the Berriasian-

928 Valanginian of northern Germany (Hornung, 2013); the Valanginian-Barremian of

929 England (Buffetaut, 1983); and the Hauterivian-Barremian of Iberia (Buscalioni and

930 Sanz, 1984, 1987b; Ruiz-Omenaca et al., 2004; Buscalioni et al., 2008; Canudo et

931 al., 2010). Indeterminate atoposaurid remains from the Cenomanian of France (Vullo

932 and Néraudeau, 2008), and mid-Coniacian Kaiparowits Formation of Utah, US (Eaton

933 et al., 1999), as well as Theriosuchus-like teeth from the Santonian of Hungary (Osi

934 et al., 2012) and the Upper Campanian-Maastrichtian of Portugal (Galton, 1996),

935 bridge the temporal gap between these Late Jurassic-Early Cretaceous atoposaurid

936 remains and Theriosuchus sympiestodon from the latest Cretaceous of Romania

937 (Martin et al., 2010, 2014). They also hint at a cryptic diversity of mid-Late

938 Cretaceous atoposaurids, as well as their presence in North America. Additionally,

939 tracks from the Kimmeridgian of Asturias, Spain (Avanzini et al., 2010), might be

940 attributable to atoposaurids, extending their Late Jurassic geographic range. The

941 taxonomic utility of crocodyliform teeth clearly requires further investigation, and

942 may help to resolve scenarios where multiple, but clearly distinct, tooth

943 morphotypes are present in the same locality (e.g., the presence of atoposaurid-like

944 teeth alongside Theriosuchus throughout the late Berriasian-early Aptian Wealden

945 Group, UK; Sweetman, 2011).

946 It is possible that the high diversity of Late Jurassic to Early Cretaceous

947 European atoposaurids is related to the island archipelago system that existed

948 during this time (Fig. 1), with epicontinental seas driven by fluctuating highstand sea

949 levels (Ziegler, 1988; Schwarz and Salisbury, 2005; Miller et al., 2005). The

950 separation of areas (e.g., basins in present day Cerin and Bavaria) might have led to

951 allopatric speciation, evidenced by closely related species found in each region (i.e., 
952 Alligatorellus beaumonti, Alligatorium meyeri and Atoposaurus jourdani in Cerin, and

953 Alligatorellus bavaricus, Alligatorium franconicum and Atoposaurus oberndorferi in

954 Bavaria). The small body size of atoposaurids in general might also be explained by

955 these environmental conditions, via ecological partitioning with other contemporary

956 crocodyliforms, including thalattosuchians and goniopholidids. There is potentially

957 evidence for niche partitioning in the Early Cretaceous of western Europe, when

958 comparably small-bodied bernissartiid crocodylomorphs lived alongside

959 Theriosuchus. Whereas both groups had a heterodont dentition, bernissartiids also

960 possessed tribodont teeth, suited to a durophagous or conchifragous diet (Buffetaut

961 and Ford, 1979; Sweetman et al., in press). This dietary partitioning might have

962 been key to two otherwise similar groups living side-by-side. It is also possible that

963 the small body size of atoposaurids (and potentially bernissartiids) reflects insular

964 dwarfism driven by a sea level-driven reduction in range size, as also proposed for

965 the contemporaneous Late Jurassic German sauropod dinosaur Europasaurus

966 (Sander et al., 2006; Marpmann et al., in press). This reasoning is also supported by

967 the persistence of atoposaurids into the Maastrichtian as part of an assemblage of

968 insular island dwarfs in a range of environments and localities, including the Haţeg

969 Basin of Romania (Benton et al., 2010; Csiki and Benton, 2010; Martin et al., 2010;

970 2014). Dwarf crocodiles are also known from the Quaternary of the Aldabara Atoll

971 (western Indian Ocean), with Aldabrachampsus dilophus (Brochu, 2006) indicating

972 that island dwarfism in crocodylomorphs might not be an uncommon feature. The

973 existence of three sympatric lineages of the dwarf crocodile Osteolaemus in present

974 day western Africa (Eaton et al., 2009; Shirley et al., 2013) also supports the idea

975 that atoposaurids could similarly have had multiple co-existing lineages, such as

976 that seen in the French and German basins.

977 Currently, testing of these hypotheses is limited as a result of the small

978 number of localities preserving atoposaurids. To support the hypothesis of insular

979 dwarfism, basal members of Atoposauridae should be expected to be much larger

980 than these Late Jurassic European forms; however, we will only be able to

981 demonstrate this with the discovery of well preserved, stratigraphically older forms,

982 from non-island archipelago settings.

\section{Conclusions}

984 We have presented a new description of a Late Jurassic German atoposaurid

985 specimen previously referred to a subspecies of Alligatorellus beaumonti, otherwise 
986 known only from coeval deposits in France. We recognise it as a distinct species of 987 Alligatorellus, based on numerous features across the skeleton, and re-rank it as 988 Alligatorellus bavaricus. Emended diagnoses are provided for the genus, as well as 989 the French and German species. Comparisons with contemporaneous atoposaurids 990 support the validity of Atoposaurus and Alligatorium, alongside Alligatorellus, with a 991 species of each genus present in Late Jurassic basins in both France and Germany, 992 providing evidence for sea level-driven allopatric speciation.

\section{Acknowledgements}

994 We are grateful to Oliver Rauhut (LMU), Didier Berthet (MNHN), Lorna Steel 995 (NHMUK), Herman Voogd (TMH) and Daniela Schwarz-Wings (MfN) for providing 996 access to specimens in their care. Comments from Trevor Valle and Joseph Hancock 997 greatly improved an earlier draft of this manuscript, and we are especially grateful 998 to Mark Young and Steve Sweetman for their reviews that substantially enhanced 999 this study. Additionally, we would like to thank Matt Wedel for his input as Editor. JPT 1000 is funded by a NERC PhD studentship (EATAS G013 13). PDM's research is funded by 1001 an Imperial College London Junior Research Fellowship.

\section{References}

1003 Adams, T. L. (2013) A new neosuchian crocodyliform from the Lower Cretaceous 1004 (Late Aptian) Twin Mountains Formation of north-central Texas, Journal of Vertebrate 1005 Paleontology, 33, 85-101

1006 Ammon, L. von (1906) Über Jurassische krokodile aus Bayern. Geognostische 1007 Jahresheften, 18, 56-71

1008 Avanzini, M., Piñuela, L. and Garcia-Ramos, J. C. (2010) Preservational morphotypes 1009 of Crocodylopodus from the Late Jurassic of Asturias (Spain), In: Crocodyle Tracks 1010 and Traces, Milàn, J., Lucas, S. G. Lockley, M. G. and Spielmann, J. A. (eds.), New 1011 Mexico Museum of Natural History and Science, Bulletin 51, 239-244

1012 Benton, M. J. and Clark, J. M. (1988) Archosaur phylogeny and the relationships of 1013 the Crocodylia, In: The Phylogeny and Classification of Tetrapods, Volume 1: 1014 Amphibians, Reptiles and Birds, Benton, M. J. (ed.), Systematics Association, 1015 Clarendon Press, Oxford, 295-338 
1016 Benton, M. J., Csiki, Z., Grigorescu, D., Redelstorff, R., Sander, M., Stein, K. and 1017 Weishampel, D. B. (2010) Dinosaurs and the island rule: the dwarfed dinosaurs from 1018 Haţeg Island, Palaeogeography, Palaeoclimatology, Palaeoecology, 293, 438-454

1019 Brinkmann, W. (1989) Vorläufige Mitteilung über die Krokodilier-Faunen aus dem 1020 Ober-Jura (Kimmeridgium) der Kohlegrube Guimarota, bei Leiria (Portugal) und der 1021 Unter-Kreide (Barremium) von Uña (Provinz Cuenca, Spanien), Documenta Naturae, $1022 \quad 56,1-28$

1023 Brinkmann, W. (1992) Die krokodilier-fauna aus der Unter-Kreide (Ober-Barremium) 1024 von Uña (Provinz Cuenca, Spanien), Berliner Geowissenschaftliche Abhandlungen, 5, $1025 \quad 1-123$

1026 Brochu, C. A. (1996) Closure of neurocentral sutures during crocodilian ontogeny: 1027 implications for maturity assessment in fossil archosaurs, Journal of Vertebrae 1028 Paleontology, 16, 49-62

1029 Brochu, C. A. (1997) A review of "Leidyosuchus" (Crocodyliformes, Eusuchia) from 1030 the Cretaceous through Eocene of North America, Journal of Vertebrate 1031 Paleontology, 17, 679-697

1032 Brochu, C. A. (2006) A new miniature horned crocodile from the Quaternary of 1033 Aldabara Atoll, western Indian Ocean, Copeia, 2, 149-158

1034 Brochu, C. A., Wagner, J. R., Jouve, S., Sumrall, C. D., Densmore, L. D. (2009) A 1035 correction corrected: consensus over the meaning of Crocodylia and why it matters, 1036 Systematic Biology, 58, 537-543

1037 Broili, F. (1931) Die gattung Alligatorium im oberen Jura von Franken, 1038 Sitzungsberichte der Bayer Akadamie der Wissenschaften. Mathematika und 1039 Naturwissenschaften, Abteilung, 63-74

1040 Buchwitz, M., Foth, C., Kogan, I. and Voigt, S. (2012) On the use of osteoderm 1041 features in a phylogenetic approach on the internal relationships of the 1042 Chronosuchia (Tetrapoda: Reptiliomorpha), Palaeontology, 55(3), 623-640

1043 Buffetaut, E. (1981) Un Atoposauridé (Crocodylia, Mesosuchia) du Portlandien de la 1044 Meuse (Est de La France), Geobios, 14, 815-819 
1045 Buffetaut, E. (1982) Radiation évolutive, paleoecology et biogéographie des 1046 crocodiliens mesosuchians, Mémoires de la Société Géologique de France, 142, 1-88

1047 Buffetaut, E. (1983) The crocodilian Theriosuchus Owen, 1879, in the Wealden of 1048 England, Bulletin of the British Museum of Natural History, 37, 93-97

1049 Buffetaut, E. and Ford, R. L. E. (1979) The crocodilian Bernissartia in the Wealden of 1050 the Isle of Wight, Palaeontology, 22, 905-912

1051 Burns, M. E. (2008) Taxonomic utility of ankylosaur (Dinosauria, Ornithischia) 1052 osteoderms: Glyptodontopelta mimus Ford, 2000: a test case, Journal of Vertebrate 1053 Paleontology, 28, 1102-1109

1054 Buscalioni, A. D. and Sanz, J. L. (1984) Los Arcosaurios (Reptilia) del Jurásico Superior 1055 - Cretácico Inferior de Galve (Tereul, España), Separata de la Revista Tereul, 71, 9105628

1057 Buscalioni, A. D. and Sanz, J. L. (1987a) Cocodrilos del Cretacico Inferior de Galve 1058 (Tereul, España), Estudios Geologicos, Vol. Extraord, Galve-Tremp, 43, 23-43

1059 Buscalioni, A. D. and Sanz, J. L. (1987b) Lista faunistica de los vertebrados de Galve 1060 (Teruel), Estudios Geologicos, Vol. Extraord, Galve-Tremp, 43, 65-67

1061 Buscalioni, A. D. and Sanz, J. L. (1988) Phylogenetic relationships of the 1062 Atoposauridae (Archosauria, Crocodylomorpha), Historical Biology, 1, 233-250

1063 Buscalioni, A. D. and Sanz, J. L. (1990a) Montsecosuchus depereti (Crocodylomorpha, 1064 Atoposauridae), new denomination for Alligatorium depereti Vidal, 1915 (Early 1065 Cretaceous, Spain): redescription and phylogenetic relationships, Journal of 1066 Vertebrate Paleontology, 10, 244-254

1067 Buscalioni, A. D. and Sanz, J. L. (1990b) La familia Atoposauridae: una aproximacíon 1068 a la historia de los cocodrilos enanos, Treballs del Museu de Geologia de Barcelona, $1069 \quad \mathbf{1}, 77-89$

1070 Buscalioni, A. D., Fregenal, M. A., Bravo, A., Poyato-Ariza, F. J., Sanchiz, B., Baez, A. 1071 M., Moo, O. C., Closas, C. M., Evans S. E. and Lobon, J. M. (2008) The vertebrate 1072 assemblage of Buenache de la Sierra (Upper Barremian of Serrania de Cuenca, 
1073 Spain) with insights into its taphonomy and palaeoecology, Cretaceous Research, 1074 29, 687-710

1075 Canudo, J. I., Gasca, J. M., Aurell, M., Badiola, A., Blain, A.-H., Cruzado-Caballero, P., 1076 Gomez-Fernandez, D., Moreno-Azanza, M., Parrilla, J., Rabal-Garces, R. and Ruiz1077 Omenaca, J. I. (2010) La Cantalera: an exceptional window onto the vertebrate 1078 biodiversity of the Hauterivian-Barremian transition in the Iberian Peninsula, Journal 1079 of Iberian Geology, 36, 205-224

1080 Cifelli, R. L., Nydam, R. L., Eaton, J. G., Gardner, J. D. and Kirkland, J. I. (1999) 1081 Vertebrate faunas of the North Horn Formation (Upper Cretaceous-Lower Paleocene), 1082 Emery and Sanpete counties, Utah, Vertebrate Paleontology in Utah, 99, 377-388

1083 Chentanez, T., Huggins, S. E. and Chentanez, V. (1983) Allometric relationships of 1084 the Siamese crocodile, Crocodylus siamensis, Journal of the Science Society of 1085 Thailand, 91, 5-26

1086 Clark, J. M. (1986) Phylogenetic relationships of the crocodylomorph archosaurs, 1087 Unpublished PhD Thesis, Department of Anatomy, University of Chicago, 551 pp.

1088 Clark, J. M. and Sues, H.-D. (2002) Two new basal crocodylomorph archosaurs and 1089 the monophyly of the Sphenosuchia, Zoological Journal of the Linnean Society, 136, 1090 77-95

1091 Csiki, Z. and Benton, M. J. (2010) An island of dwarfs - reconstructing the Late 1092 Cretaceous Haţeg palaeoecosystem, Palaeogeography, Palaeoclimatology, 1093 Palaeoecology, 293, 265-270

1094 Cuny, G., Laojumpon, C., Cheychiw, O. and Lauprasert, K. (2010) Fossil vertebrate 1095 remains from the Kut Island (Gulf of Thailand, Early Cretaceous), Cretaceous 1096 Research, 31, 415-423

1097 Delfino, M. and Dal Sasso, C. (2006) Marine reptiles (Thalattosuchia) from the Early 1098 Jurassic of Lombardy (northern Italy), Geobios, 39, 346-354

1099 Delfino, M. and Sánchez-Villagra, M. R. (2010) A survey of the rock record of reptilian 1100 ontogeny, Seminars in Cell \& Developmental Biology, 21, 432-440 
1101 Delfino, M., Codrea, V., Folie, A., Dica, P., Godefroit, P and Smith, T. (2008) A 1102 complete skull of Allodaposuchus precedens Nopsca, 1928 (Eusuchia) and a 1103 reassessment of the morphology of the taxon based on the Romanian remains, 1104 Journal of Vertebrate Paleontology, 28, 111-122

1105 Dodson, P. (1975) Functional and ecological significance of relative growth in 1106 Alligator, Journal of Zoology, 175, 315-355

1107 Eaton, J. G.., Cifelli, R. L., Hutchison, J. H., Kirkland, J. I. and Parrish, J. M. (1999) 1108 Cretaceous vertebrate faunas from the Kaiparowits Plateau, South-Central Utah, In: 1109 Vertebrate Paleontology in Utah, eds: Gillette, D. E., Utah Geological Survey, 1110 Miscellaneous Publication, 345-353

1111 Eaton, M. J., Martin, A., Thorbjarnarson, J. and Amato, G. (2009) Species-level 1112 diversification of African dwarf crocodiles (genus Osteolaemus): a geographic and 1113 phylogenetic perspective, Molecular Phylogenetics and Evolution, 50, 496-506

1114 Efimov, M. B. (1976) The oldest crocodile on the territory of the USSR, 1115 Paleontologicheskii Zhurnal, 10, 115-117

1116 Evans, S. E. and Milner, A. R. (1994) Microvertebrate faunas from the middle Jurassic 1117 of Britain, In: The Shadow of the Dinosaurs: Early Mesozoic Tetrapods, eds: Fraser, N. 1118 C. and Sues, H.-D., 303-321, Cambridge University Press, Cambridge

1119 Fiorillo, A. R. (1999) Non-mammalian microvertebrate remains from the Robison 1120 Eggshell Site, Cedar Mountain Formation (Lower Cretaceous), Emery County, Utah, 1121 In: Vertebrate Paleontology in Utah, D. D. Gilette, ed., Utah Geological Survey 1122 Miscellaneous Publications, 99, 259-268

1123 Foth, C. (2013) Ontogenetic, macroevolutionary and morphofunctional patterns in 1124 archosaur skulls: a morphometric approach, Unpublished PhD Thesis, Fakultät für 1125 Geowissenschaften, Ludwig-Maximilians-Universität, München, 369 pp.

1126 Galton, P. M. (1996) Notes on Dinosauria from the Upper Cretaceous of Portugal, 1127 Neueus Jahrbuch fur Geologie und Paläontology, Mitheilung, 2, 83-90

1128 Gervais, P. (1871) Remarques au sujet des Reptiles provenant des calcaires 1129 lithographiques de Cerin, dans le Bugey, qui sont conservés au Musée de Lyon, 1130 Comptes Rendus des Séances de l'Academie de Sciences, 79-83 
1131 Gilmore, C. W. (1926) A new aetosaurian reptile from the Morrison Formation of

1132 Utah, Annals of Carnegie Museum, 16, 325-348

1133 Hay, O. P. (1930) Second Bibliography and Catalogue of the Fossil Vertebrate of

1134 North America, Carnegie Institution Publications, Washington, 1990 pp.

1135 Hornung, J. J. (2013) Contributions to the Palaeobiology of the archosaurs (Reptilia:

1136 Diapsida) from the Bückerberg Formation ('northwest German Wealden' - Berriasian-

1137 Valanginian, Lower Cretaceous) of northern Germany, Unpublished Doctoral Thesis,

1138 Georg-August-Universität Göttingen, 405 pp.

1139 Joffe, J. (1967) The 'dwarf' crocodiles of the Purbeck Formation, Dorset: a 1140 reappraisal, Palaeontology, 10, 629-639

1141 Karl, H.-V., Groning, E., Bruackmann, C., Schwarz, D and Knötschke, N. (2006) The 1142 Late Jurassic crocodiles of the Langenberg near Oker, Lower Saxony (Germany), and 1143 description of related materials (with remarks on the history of quarrying in the 1144 "Langenberg Limestone" and "Obernkirchen Sandstone"), Clausthaler 1145 Geowissenschaften, 5, 59-77

1146 Knoll, F., Cuny, G., Mojon, P.-O., López-Antoñanzas, R. and Huguet, D. (2013) A new 1147 vertebrate-, ostracod-, and charophyte-bearing locality in the Middle Jurassic of the 1148 Grands Causses (southern France), Proceedings of the Geologists' Association, 124 $1149 \quad 525-529$

1150 Kriwet, J., Rauhut, O. W. M. and Gloy, U. (1997) Microvertebrate remains (Pisces, 1151 Archosauria) from the Middle Jurassic (Bathonian) of France, Neues Jahrbuch für 1152 Geologie und Paläontologie, 206, 1-28

1153 Kuhn, O. (1961) Die Tier-und pflanzenweit des Solnhofener Schiefers, Geologica 1154 Bavarica, 48, 70 pp.

1155 Lauprasert, K., Cuny, G., Buffetaut, E., Suteethorn, V. and Thirakhupt, K. (2008) First 1156 occurrences of atoposaurid crocodyliforms in the Late Jurassic and Early Cretaceous 1157 of the Khorat Plateau, Northeastern Thailand, 6th Meeting of the European 1158 Association of Vertebrate Palaeontologists

1159 Lauprasert, K., Laojumpon, C., Saenphala, W., Cuny, G., Thirakhupt, K. and 1160 Suteethorn, V. (2011) Atoposaurid crocodyliforms from the Khorat Group of Thailand: 
1161 first record of Theriosuchus from Southeast Asia, Palaeontologische Zeitschrift, 85, $1162 \quad 37-47$

1163 Marpmann, J. S., Carballido, J. L., Sander, P. M. and Knötschke, N. (in press) Cranial 1164 anatomy of the Late Jurassic dwarf sauropod Europasaurus holgeri (Dinosauria, 1165 Camarasauromorpha): ontogenetic changes and size dimorphism, Journal of 1166 Systematic Palaeontology, DOI: 10.1080/14772019.2013.875074

1167 Martin, J. E., Rabi, M., and Csiki, Z. (2010) Survival of Theriosuchus 1168 (Mesoeucrocodylia: Atoposauridae) in a Late Cretaceous archipelago: a new species 1169 from the Maastrichtian of Romania, Naturwissenschaften, 97, 845-854

1170 Martin, J. E., Rabi, M., Csiki-Sava, Z. and Vasile, Ş. (2014) Cranial morphology of 1171 Theriosuchus sympiestodon (Mesoeucrocodylia, Atoposauridae) and the widespread 1172 occurrence of Theriosuchus in the Late Cretaceous of Europe, Journal of 1173 Paleontology, 88, 444-456

1174 Meyer, H. V. (1850) Mitteilung, an Prof. Bronn gerichtet, Neues Jahrbuch fur 1175 Mineralogie, Geognosie, Geologie und Petrefakten-Kunde , 195-204

1176 Meyer, H. v. (1851) Description de l'Atoposaurus jourdani et du Sapheosaurus 1177 thiolleri, reptiles fossils des calcaires lithographiques du Bugey, Annales de la 1178 Societe d'Agriculture de Lyon, 2, 113-117

1179 Michard, J.-G., de Broin, F., Brunet, M. and Hell, J. (1990) Le plus ancient crocodilien 1180 néosuchien spécialisé a caracteres eusuchiens du continent Africain (Crétacé 1181 inférieur, Cameroun), Comptes Rendus de l'Académie des Sciences Paris, 311, 365$1182 \quad 371$

1183 Miller, K. G., Kominz, M. A., Browning, J. V., Wright, J. D., Mountain, G. S., Katz, M. E., 1184 Sugarman, P. J., Cramer, B. S., Christie-Blick, N. and Pekar, S. F. (2005) The 1185 Phanerozoic record of global sea-level change, Science, 310, 1293-1298

1186 Montefeltro, F. C., Larsson, H. C. E., de Franca, M. A. G. and Langer, M. C. (2013) A 1187 new neosuchian with Asian affinities from the Jurassic of northeastern Brazil, 1188 Naturwissenschaften, 100, 835-841 
1189 Monteiro, L. R. and Soares, M. (1997) Allometric analysis of the ontogenetic variation 1190 and evolution of the skull in Caiman Spix, 1825 (Crocodylia: Alligatoridae), 1191 Herpetologica, 62-69

1192 Monteiro, L. R., Cavalcanti, M. J. and Sommer III, H. J. S. (1997) Comparative 1193 ontogenetic shape changes in the skull of Caiman species (Crocodylia, Alligatoridae), 1194 Journal of Morphology, 231, 53-62s

1195 Mook, C. C. (1933) A crocodilian skeleton from the Morrison Formation at Canyon 1196 City, Colorado, American Museum Novitates, 671, 1-8

1197 Mook, C. C. (1942) Skull characters of Amphicotylus lucasii Cope, American Museum 1198 Novitates, 1165, 1-5

1199 Osi, A., Clark, J. M. and Weishampel, D. B. (2007) First report on a new basal 1200 eusuchian crocodyliform with multicusped teeth from the Upper Cretaceous 1201 (Santonian) of Hungary, Neues Jahrbuch fur Geologie und Palaontologie, Abhteilung, 1202 243, 169-177

1203 Ösi, A., Rabi, Makádi, L., Szentesi, Z., Botfalvai, G., and Gulyás, P. (2012) The Late 1204 Cretaceous continental vertebrate fauna from Iharkút (Western Hungary, Central 1205 Europe): a review, In: Tribute to Charles Darwin and the Bernissart Iguanodons: New 1206 Perspectives of Vertebrate Evolution and Early Cretaceous Ecosystems, ed: 1207 Godefroit, P., Indiana University Press, Bloomington, 533-570

1208 Owen, R. (1878) Monograph of the fossil Reptilia of the Wealden and Purbeck 1209 formations. Supplement No. VIII. Crocodilia (Goniopholis, Petrosuchus and 1210 Suchosaurus), Monograph of the Palaeontolographical Society, 32, 1-15

1211 Owen, R. (1879) Monograph on the fossil Reptilia of the Wealden and Purbeck 1212 formations. Supplement No. IX. Crocodilia (Goniopholis, Brachydetes, Nannosuchus, 1213 Theriosuchus and Nuthetes), Monograph of the Palaeontographical Society, 33, 1-15

1214 Parker, W. G. (2007) Reassessment of the aetosaur "Dermatosuchus" chamaensis 1215 with a reanalysis of the phylogeny of the Aetosauria (Archosauria: Pseudosuchia), 1216 Journal of Systematic Palaeontology, 5, 41-68 
1217 Parker, W. G. and Martz, J. W. (2010) Using positional homology in aetosaur

1218 (Archosauria: Pseudosuchia) osteoderms to evaluate the taxonomic status of

1219 Lucasuchus hunti, Journal of Vertebrate Paleontology, 30, 1100-1108

1220 Parilla-Bel, J., Young, M. T., Moreno-Azanza, M. and Canudo, J. I. (2013) The first 1221 metriorhynchid crocodylomorph from the Middle Jurassic of Spain, with implications 1222 for evolution of the subclade Rhacheosaurini, PLOS ONE, 8, e54275

1223 Peybernes, M. M. B. and Oertli, H. (1972) La série de passage du Jurassique au 1224 Crétacédans les Bassin sud-Pyrénéen, Comptes Rendus de l'Académie des Sciences, 1225 Paris, 274, 3348-3351

1226 Piras, P., Colangelo, P., Adams, D. C., Buscalioni, A., Cubo, J., Kotsakis, T., Meloro, C. 1227 and Raia, P. (2010) The Gavialis-Tomistoma debate: the contribution of skull 1228 ontogenetic allometry and growth trajectories to the study of crocodylian 1229 relationships, Evolution and Development, 12, 568-579

1230 Platt, S. G., Rainwater, T. R., Thorbarnarson, J. B., Finger, A. G., Anderson, T. A. and 1231 McMurry, S. T. (2009) Size estimation, morphometrics, sex ratio, sexual size 1232 dimorphism, and biomass of Morelet's crocodile in northern Belize; Caribbean 1233 Journal of Science, 45, 80-93

1234 Pol, D. and Gasparini, Z. (2009) Skull anatomy of Dakosaurus andiniensis 1235 (Thalattosuchia: Crocodylomorpha) and the phylogenetic position of Thalattosuchia, 1236 Journal of Systematic Palaeontology, 7, 163-197

1237 Pol, D., Ji, S., Clark, J. M. and Chiappe, L. M. (2004) Basal crocodyliforms from the 1238 Lower Cretaceous Tugulu Group (Xinjiang, China) and the phylogenetic position of 1239 Edentosuchus, Cretaceous Research, 25, 603-622

1240 Pol, D., Turner. A. H. and Norell, M. A. (2009) Morphology of the Late Cretaceous 1241 crocodylomorph Shamosuchus djadochtaensis and a discussion of neosuchian 1242 phylogeny as related to the origin of Neosuchia, Bulletin of the American Museum of 1243 Natural History, 103, 1-103

1244 Poueche, J., Mazin, J.-M. and Billon-Bruyat, J.-P. (2006) Microvertebrate biodiversity 1245 from Cherves-de-Cognac (Lower Cretaceous, Berriasian: Charente, France), Mesozoic 1246 Terrestrial Ecosystems, 96-100 
1247 Pritchard, J. C., Turner, A. H., Allen, E. R., Norell, M. A. (2013) Osteology of a North 1248 American goniopholidid (Eutretauranosuchus delfsi) and palate evolution in 1249 Neosuchia, American Museum Novitates, 3783, 1-56

1250 R Development Core Team (2014) A language and environment for statistical 1251 computing (http://www.R-project.org).

1252 Rogers, J. V. (2003) Pachycheilosuchus trinquei, a new procoelus crocodyliform from 1253 the Lower Cretaceous (Albian) Glen Rose Formation of Texas, Journal of Vertebrate, 1254 23, 128-145

1255 Ross, F. D. and Mayer, G. C. (1983) On the dorsal armour of the Crocodilia, In: 1256 Advances in Herpetology and Evolutionary Biology, ed. Rhodin, A. G. H., Cambridge, 1257 Massachusetts, Museum of Comparative Zoology, 305-331

1258 Ruiz-Omenaca. J. I., Canudo, J. I. Aurell, M., Bádenas, B., Barco, J. L., Cuenca-Bescós, 1259 G. and Ipas, J. (2004) Estado de las investigaciones sobre los vertebrados del 1260 Jurasico Superior y Cretacico Inferior de Galve (Teruel) Estudios Geologica, 60, 1791261202

1262 Salisbury, S. W. (2002) Crocodilians from the Lower Cretaceous (Berriasian) Purbeck 1263 Limestone Group of Dorset, southern England, Special Papers in Palaeontology, 68, $1264 \quad 121-144$

1265 Salisbury, S. W., Molnar, R. E., Frey, E. and Willis, P. M. A. (2006) The origin of modern 1266 crocodyliforms: new evidence form the Cretaceous of Australia, Proceedings of the 1267 Royal Society B, 273, 2439-2448

1268 Salisbury, S. W. and Naish, D. (2011) Crocodilians, In: English Wealden Fossils, Ed: D. 1269 J. Batten, The Palaeontological Association, London, 305-369

1270 Sander, P. M., Mateus, O., Laven, T. and Knötsche, N. (2006) Bone histology indicates 1271 insular dwarfism in a new Late Jurassic sauropod dinosaur, Nature, 44, 739-741

1272 Schwarz, D. and Salisbury, S. W. (2005) A new species of Theriosuchus 1273 (Atoposauridae, Crocodylomorpha) from the Late Jurassic (Kimmeridgian) of 1274 Guimarota, Portugal, Geobios, 38, 779-802 


\section{PeerJ Reviewing Manuscript}

1275 Schwarz-Wings, D., Rees, J. and Lindgren, J. (2009) Lower Cretaceous

1276 mesoeucrocodylians from Scandinavia (Denmark and Sweden), Cretaceous

1277 Research, 30, 1345-1355

1278 Schwarz-Wings, D., Klein, N., Neumann, C. and Resch, U. (2011) A new partial 1279 skeleton of Alligatorellus (Crocodyliformes) associated with echinoids from the Late 1280 Jurassic (Tithonian) lithographic limestone of Kelheim, S-Germany, Fossil Record, 14, $1281 \quad 195-205$

1282 Sertich, J. J. W. and O'Connor, P. M. (2014) A new crocodyliform from the middle 1283 Cretaceous Galula Formation, southwestern Tanzania, Journal of Vertebrate 1284 Paleontology, 34, 576-596

1285 Shirley, M. H., Vilet, K. A,. Carr, A. N. and Austin, J. D. (2013) Rigorous approaches to 1286 species delimitation have significant implications for African crocodilian systematics 1287 and conservation, Proceedings of the Royal Society B, 281, 20132483

1288 Smith, D. K., Allen, E. R., Sanders, R. K. and Stadtman, K. L. (2010) A new specimen 1289 of Eutretauranosuchus (Crocodyliformes; Goniopholididae) from Dry Mesa, Colorado, 1290 Journal of Vertebrate Paleontology, 30, 1466-1477

1291 Steel, R. (1973) Crocodylia, Part 16, In Handbuch der Paläherpetologie, Kuhn, O. 1292 (ed.), Gustav Fischer Verlag, 1-116

1293 Stevens, N. J., Hill, R. V., Al-Wosabi, M., Schulp, A., As-Saruri, M., Al-Nimey, F., Jolley, 1294 L. A., Schulp-Stuip, Y. and O'Connor, P. (2013) A middle Eocene mesoeucrocodylian 1295 (Crocodyliformes) from the Kaninah Formation, Republic of Yemen, Geologos, 19, $1296 \quad 175-183$

1297 Storrs, G. W. and Efimov, M. B. (2000) Mesozoic crocodyliforms of north-central 1298 Eurasia, In: The Age of Dinosaurs in Russia and Mongolia, Eds: Benton, M. J., Sishikin, 1299 M. A. and Unwin, D., Cambridge University Press, pp. 402-419

1300 Sweetman, S. C. (2011) Vertebrate microfossils, In: English Wealden Fossils, Ed: D. J. 1301 Batten, The Palaeontological Association, London, 192-204

1302 Sweetman, S. C., Pedreira-Segade, U. and Vidovic, S. U. (in press) A new 1303 bernissartiid crocodyliform from the Lower Cretaceous Wessex Formation (Wealden 
1304 Group, Barremian) of the Isle of Wight, southern England, Acta Palaeontologica 1305 Polonica, doi: 10.4202/app.00038.2013

1306 Thies, D., Windolf, R. and Mudroch, A. (1997) First record of Atoposauridae 1307 (Crocodylia: Metamesosuchia) in the Upper Jurassic (Kimmeridgian) of northwest 1308 Germany, Neues Jahrbuch für Geologie und Paläontologie, 205, 393-411

1309 Turner, A. H. and Buckley, G. A. (2008) Mahajangasuchus insignis (Crocodyliformes: 1310 Mesoeucrocodylia) cranial anatomy and new data on the origin of the eusuchian1311 style palate, Journal of Vertebrate Paleontology, 28, 382-408

1312 Verdade, L. M. (2000) Regression equations between body and head measurements 1313 in the broad-snouted caiman (Caiman latirsotris), Revista Brasileira de Biologia, 60, $1314 \quad 469-482$

1315 Vickaryous, M. K. and Hall, B. K. (2008) Development of the dermal skeleton in 1316 Alligator mississippiensis (Archosauria, Crocodylia) with comments on the homology 1317 of osteoderms, Journal of Morphology, 269, 398-422

1318 Vidal, L. M. (1915) Nota geologica y paleontologica sobre e Jurasico Superior de la 1319 Provincia de Lérida, Boliten del Instetuto Geológico de Espana, 16, 17-55

1320 Vullo, R. and Néraudeau, D. (2008) Cenomanian vertebrate assemblages from 1321 southwestern France: a new insight into the European mid-Cretaceous continental 1322 fauna, Cretaceous Research, 29, 930-935

1323 Walker, A. D. (1970) A revision of the Jurassic reptile Hallopus victor (Marsh), with 1324 remarks on the classification of crocodiles, Philosophical Transactions of the Royal 1325 Society of London, $B, \mathbf{2 5 7}, 323-372$

1326 Wellnhofer, P. (1971) Die Atoposauridae (Crocodylia, Mesosuchia) der Oberjura1327 Plattenkalke Bayerns, Palaeontographica Abteilung A, 138, 133-165

1328 Whetstone, K. N. and Whybrow, P. J. (1983) A "cursorial" crocodilian from the Triassic 1329 of Lesotho (Basutoland), southern Africa, Occasional Papers of the Museum of 1330 Natural History, University of Kansas, 106, 1-37

1331 Wings, O., Schwarz-Wings, D., Pfretzschner, H.-U. and Martin, T. (2010) Overview of 1332 Mesozoic crocodylomorphs from the Junggar Basin, Xinjiang, northwest China, and 
1333 description of isolated crocodyliform teeth from the Late Jurassic Liuhuanggou

1334 locality, Palaeobiodiversity and Palaeoenvironments, 90, 283-294

1335 Wu, X. B., Xue, H., Wu, L. S., Zhu, J. L. and Wang, R. P. (2006) Regression analysis 1336 between body and head measurements of Chinese alligators (Alligator sinensis) in 1337 the captive population, Animal Biodiversity and Conservation, 29, 65-71

1338 Wu, X,-C., Brinkman, D. B. and Lu, J.-C (1994) A new species of Shantungosuchus 1339 from the Lower Cretaceous of Inner Mongolia (China), with comments on $S$. 1340 chuhsienensis Young, 1961 and the phylogenetic position of the genus, Journal of 1341 Vertebrate Paleontology, 14, 210-219

1342 Wu, X.-C., Sues, H.-D., Brinkman, D. B. (1996) An atoposaurid neosuchian 1343 (Archosauria: Crocodyliformes) from the Lower Cretaceous of Inner Mongolia 1344 (People's Republic of China), Canadian Journal of Earth Science, 33, 599-605

1345 Wu, X.-C., Sues, H.-D. and Dong, Z.-M. (1997) Sichuanosuchus shuhanensis, a new ? 1346 Early Cretaceous protosuchian (Archosauria: Crocodyliformes) from Sichuan (China), 1347 and the monophyly of Protosuchia, Journal of Vertebrate Paleontology, 17, 89-103

1348 Young, C. C. (1961) On a new crocodile from Chuhsien, E. Shantung, Vertebrata 1349 Palasiatica, 1, 6-10

1350 Young, M. T., Brusatte, S. L., Ruta, M. and Andrade, M. B., (2010) The evolution of 1351 Metriorhynchoidea (Mesoeucrocodylia, Thalattosuchia): an integrated approach 1352 using geometric morphometrics, analysis of disparity and biomechanics, Zoological 1353 Journal of the Linnean Society, 158, 801-859

1354 Ziegler, P. (1988) Evolution of the Arctic-North Atlantic and Western Tethys, Memoir 1355 of the American Association of Petroleum Geologists, 43, 63-82 


\section{Figure 1}

Figure 1.

(A) Geographic distribution of Late Jurassic atoposaurid specimen localities. 1: Cerin; 2:

Kelheim; 3: Painten; 4: Solnhofen; 5: Guimarota; 6: Andrès; 7: Langenberg; 8: Uppen. Note that those localities not mentioned in the text all include occurrences of indeterminate remains of Theriosuchus; (B) Approximate palaeogeographic distribution of Late Jurassic atoposaurids. Map reconstruction from Ron Blakey, Colorado Plateau Geosystems, Arizona USA ( http://cpgeosystems.com/paleomaps.html ).
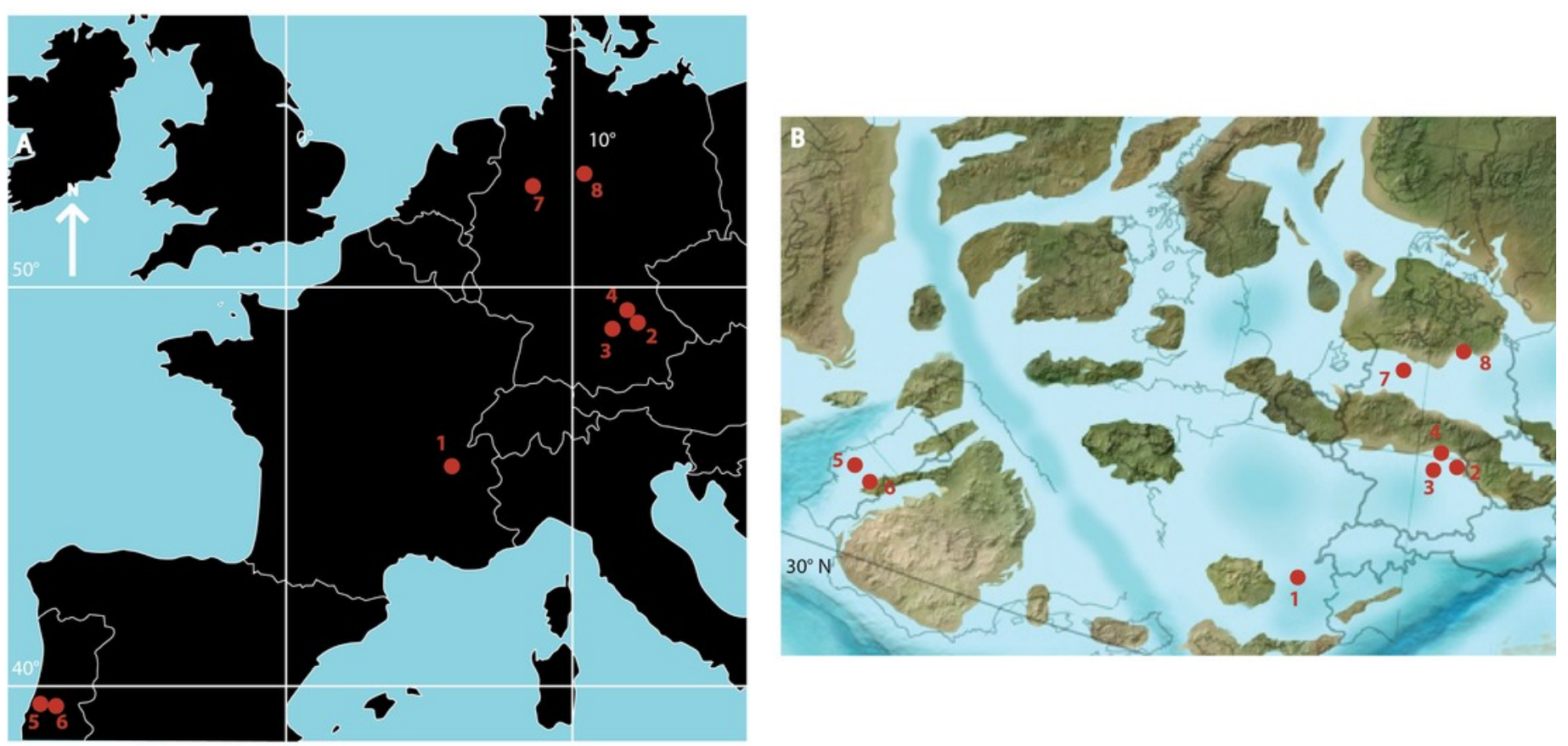


\section{Figure 2}

Figure 2.

Stratigraphic (including uncertainty) and geographic ranges of known and putative (denoted with a "?") atoposaurid species.

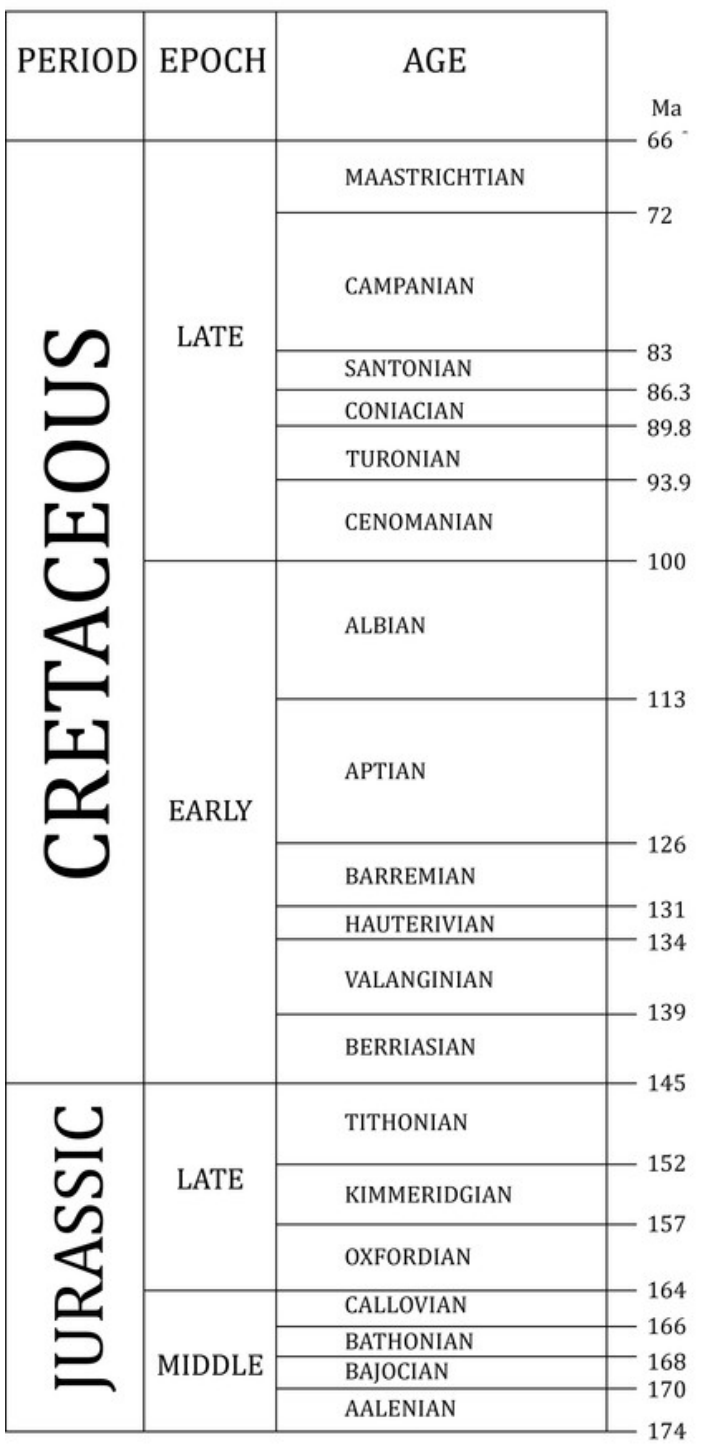

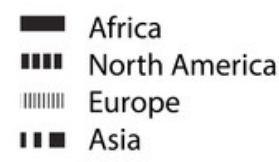

IIIIIIII) Europe

II Asia
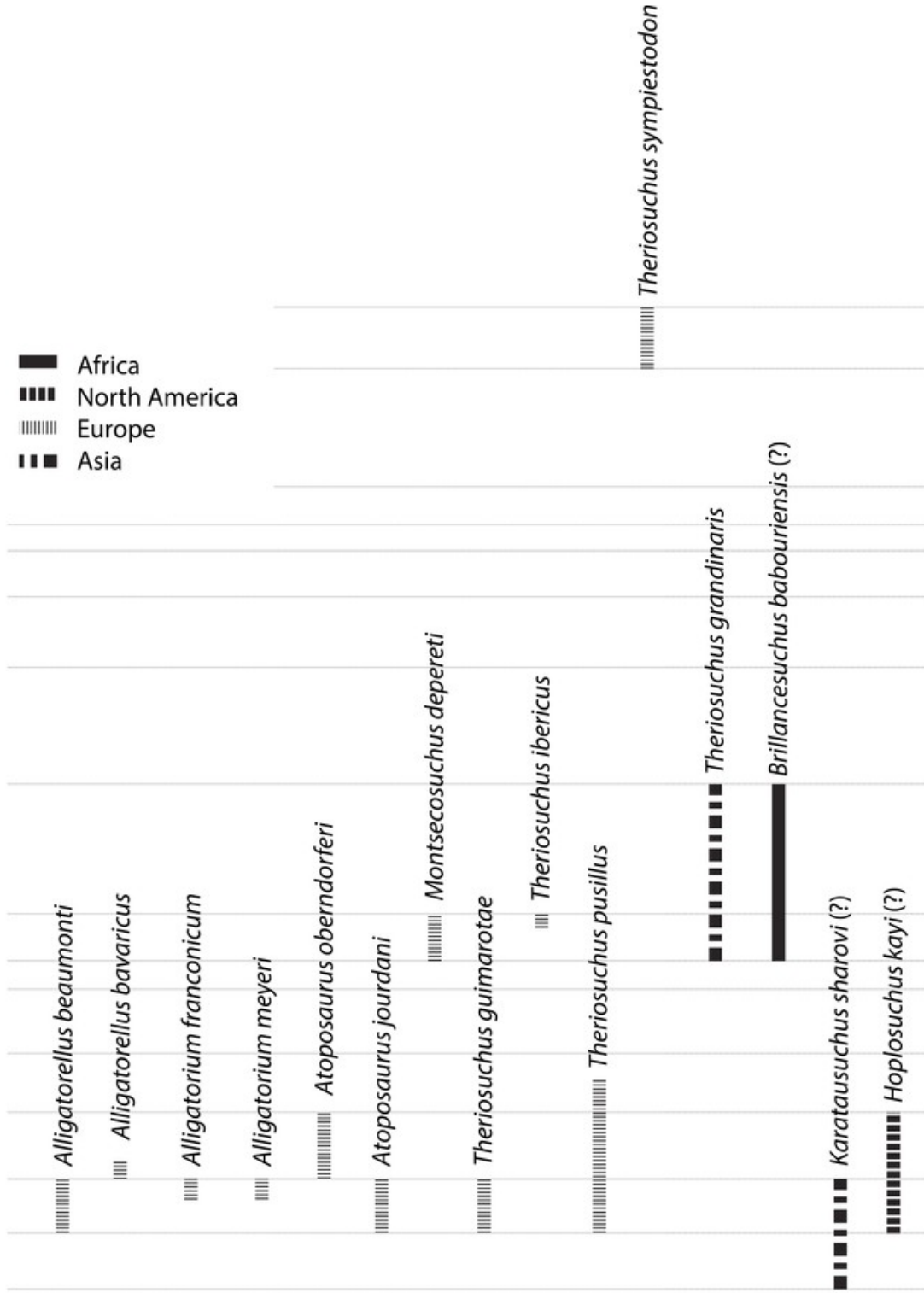


\section{Figure 3}

Figure 3.

(A) Line drawing of holotype specimen of Alligatorellus beaumonti (MNHN 15639) in dorsolateral view; (B) photograph of holotype specimen. 

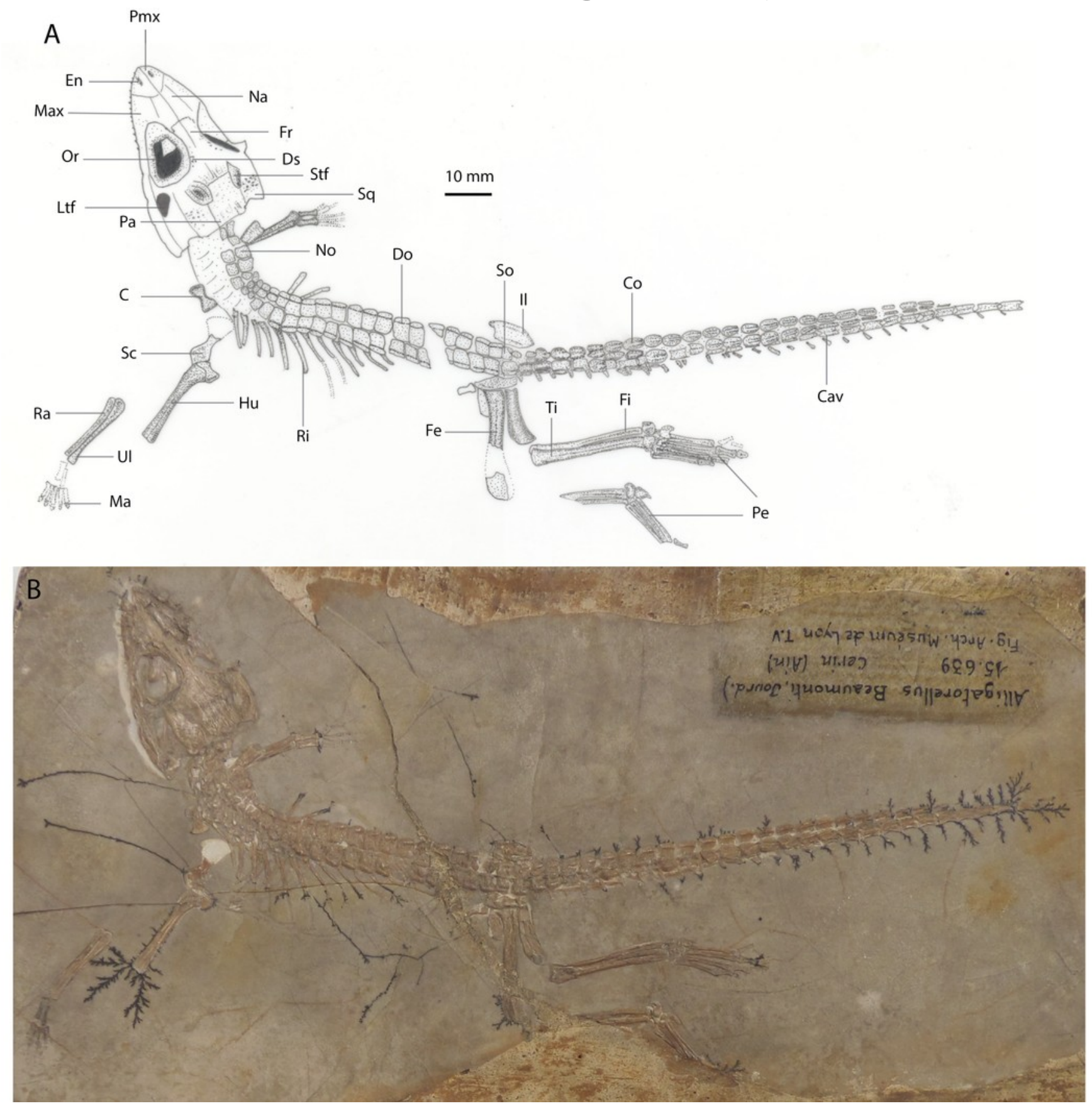


\section{Figure 4}

Figure 4.

(A) Line drawing of referred specimen of Alligatorellus beaumonti (MNHN 15638) in dorsoventral view; (B) photograph of referred specimen.

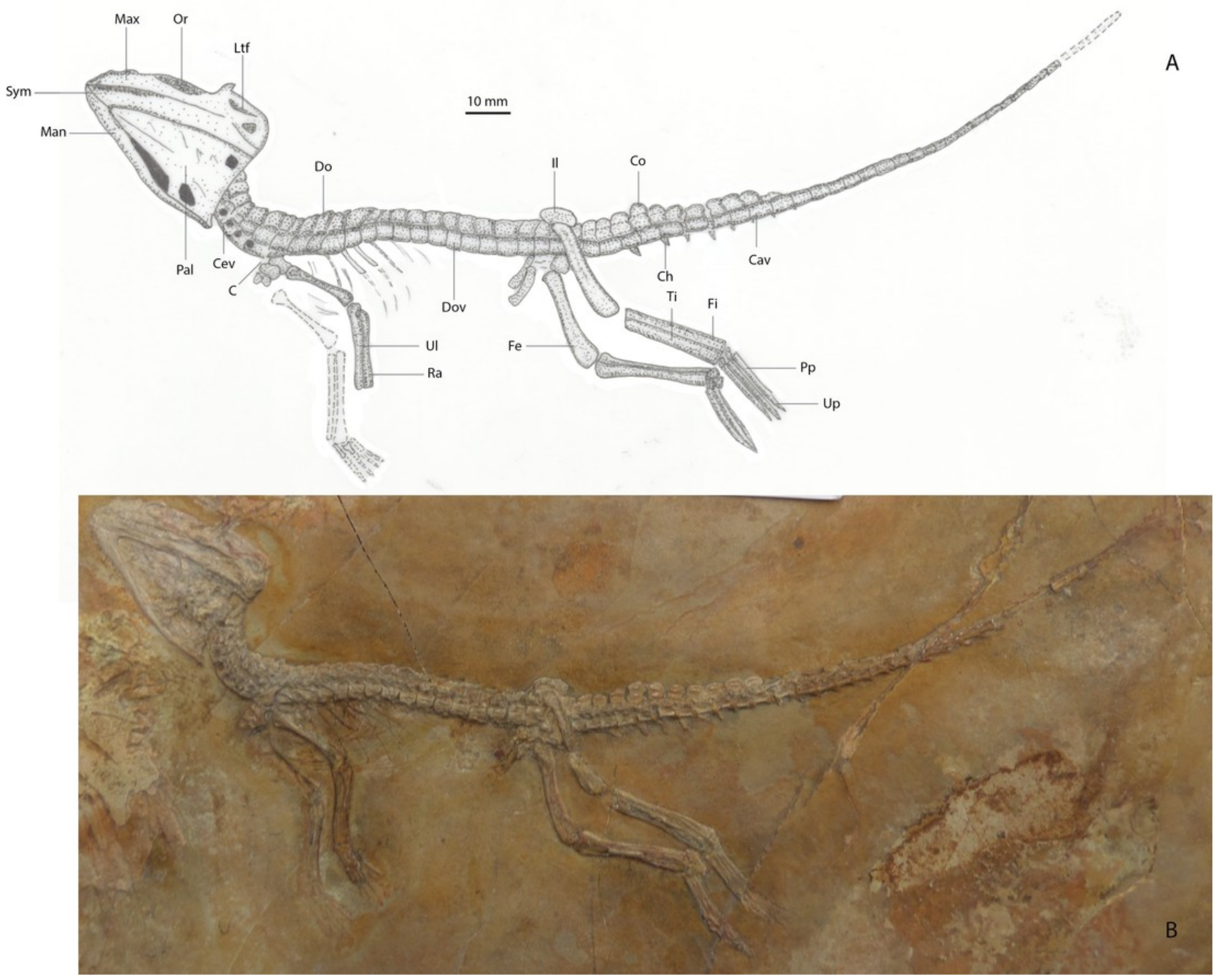




\section{Figure 5}

Figure 5.

(A) Line drawing of holotype specimen of Alligatorellus bavaricus (LMU 1937 I 26) in dorsolateral view; (B) photograph of holotype specimen.

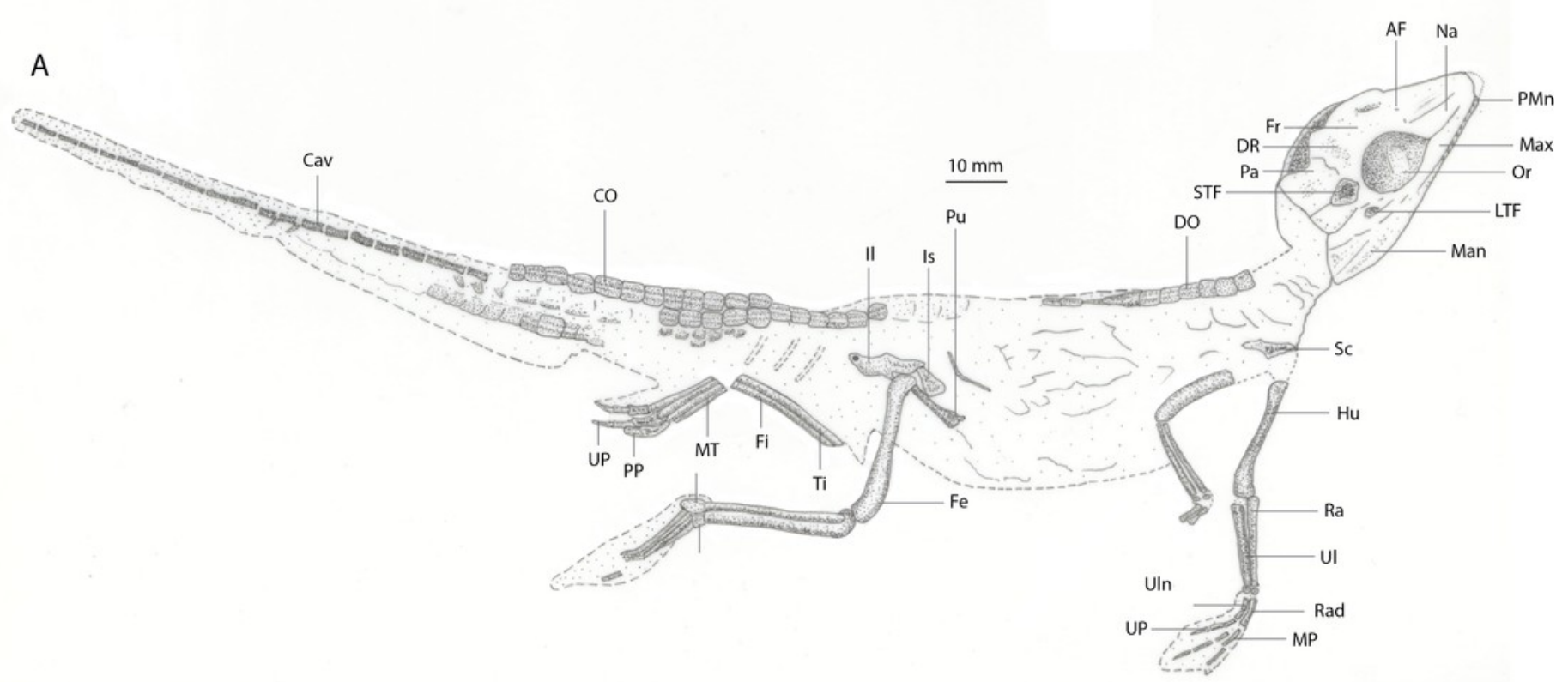

B 


\section{Figure 6}

Figure 6.

Photograph and line drawing of the skull of the holotype specimen of Alligatorellus beaumonti (MNHN 15639) in dorsal aspect.
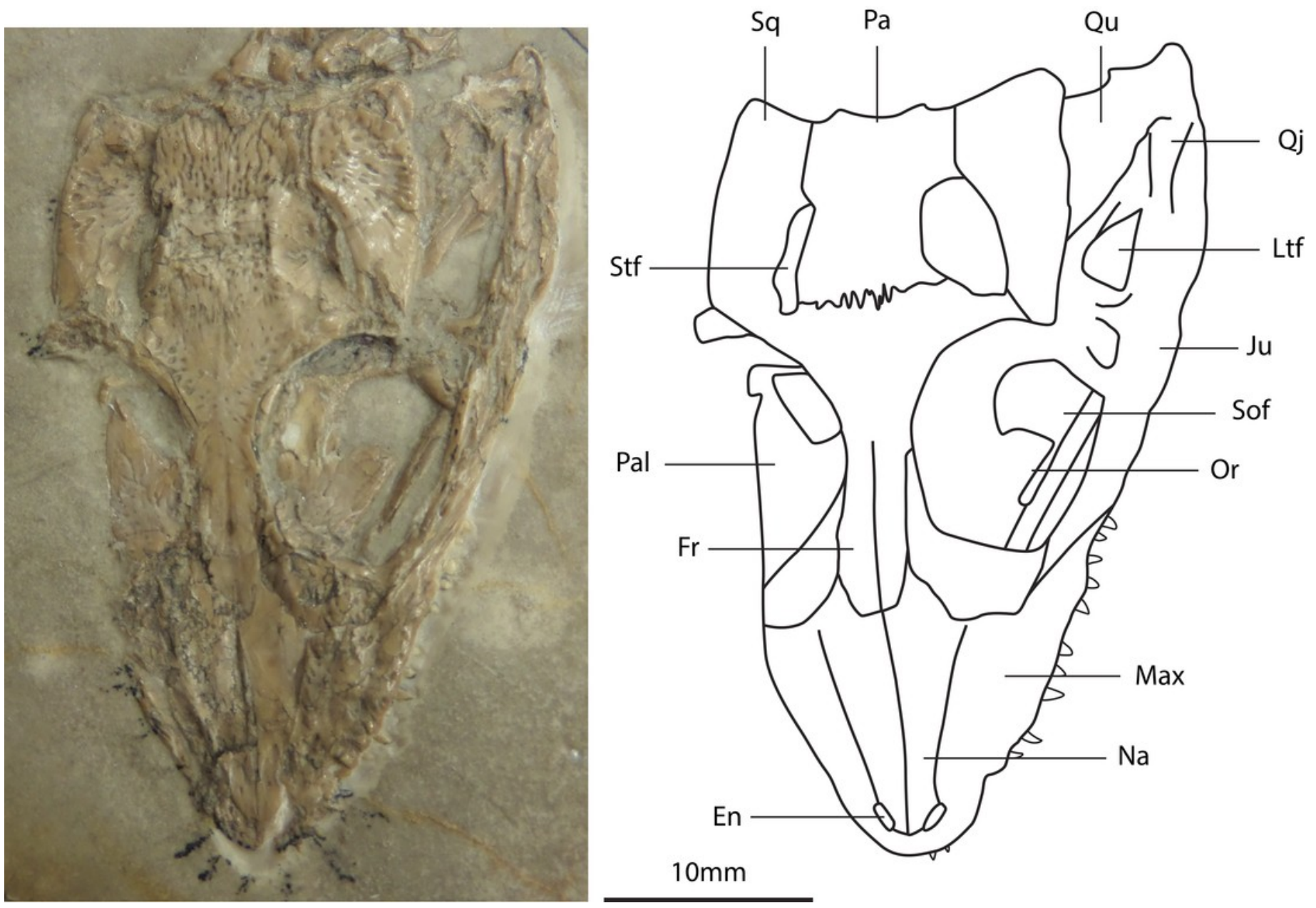


\section{Figure 7}

Figure 7.

Photograph and line drawing of the skull of the holotype specimen of Alligatorellus bavaricus (LMU 1937 I 26) in dorsolateral aspect.
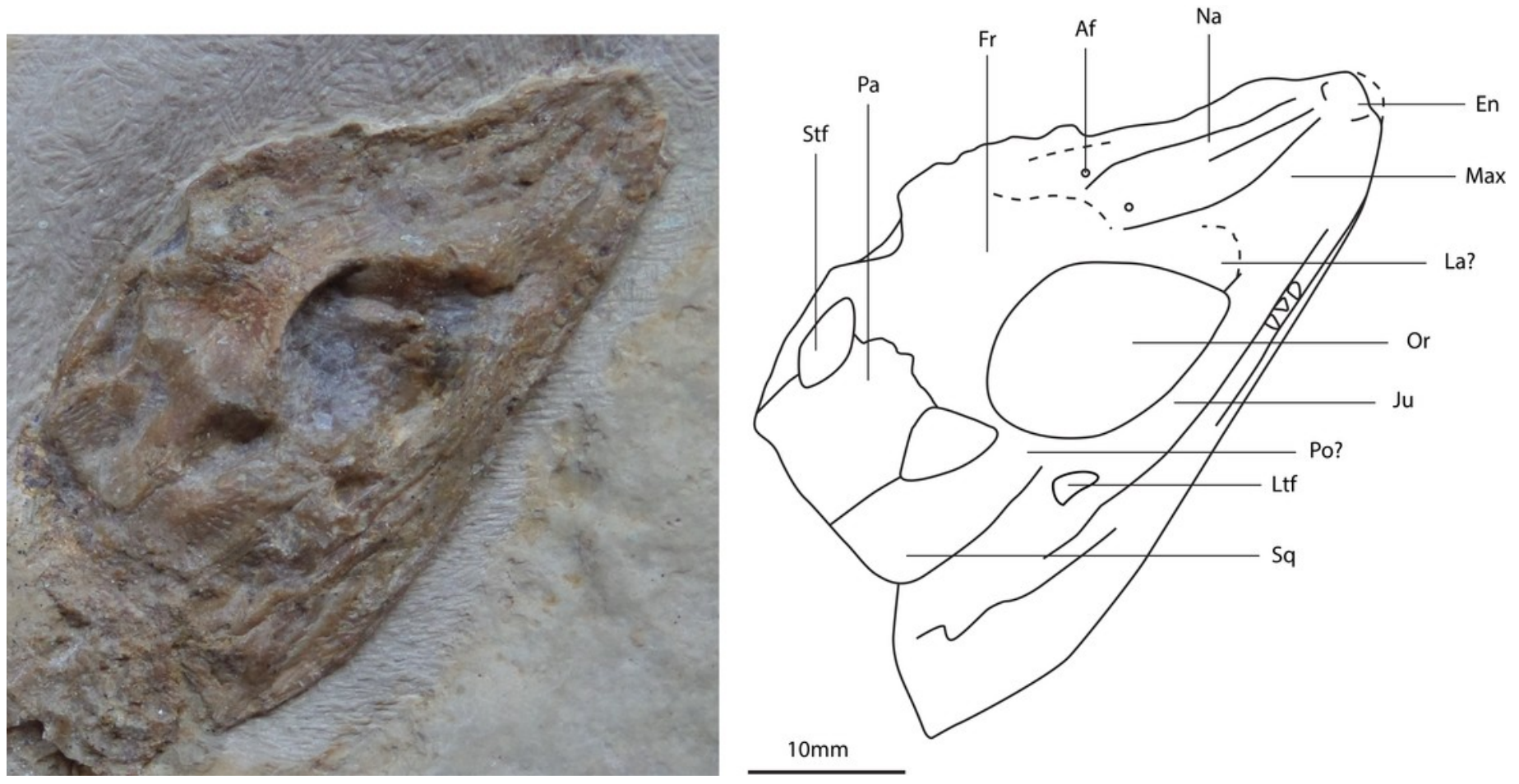


\section{Figure 8}

Figure 8.

(A) Line drawings of the dorsal osteoderms of $A$. bavaricus; (B) line drawings of the cervical and dorsal osteoderm series of $A$. beaumonti; (C) Line drawing of a dorsal osteoderm of the specimen described as Alligatorellus sp. (MfN MB. R. 4317.1-12) by Schwarz-Wings et al. (2011), but considered here as Atoposauridae indet.

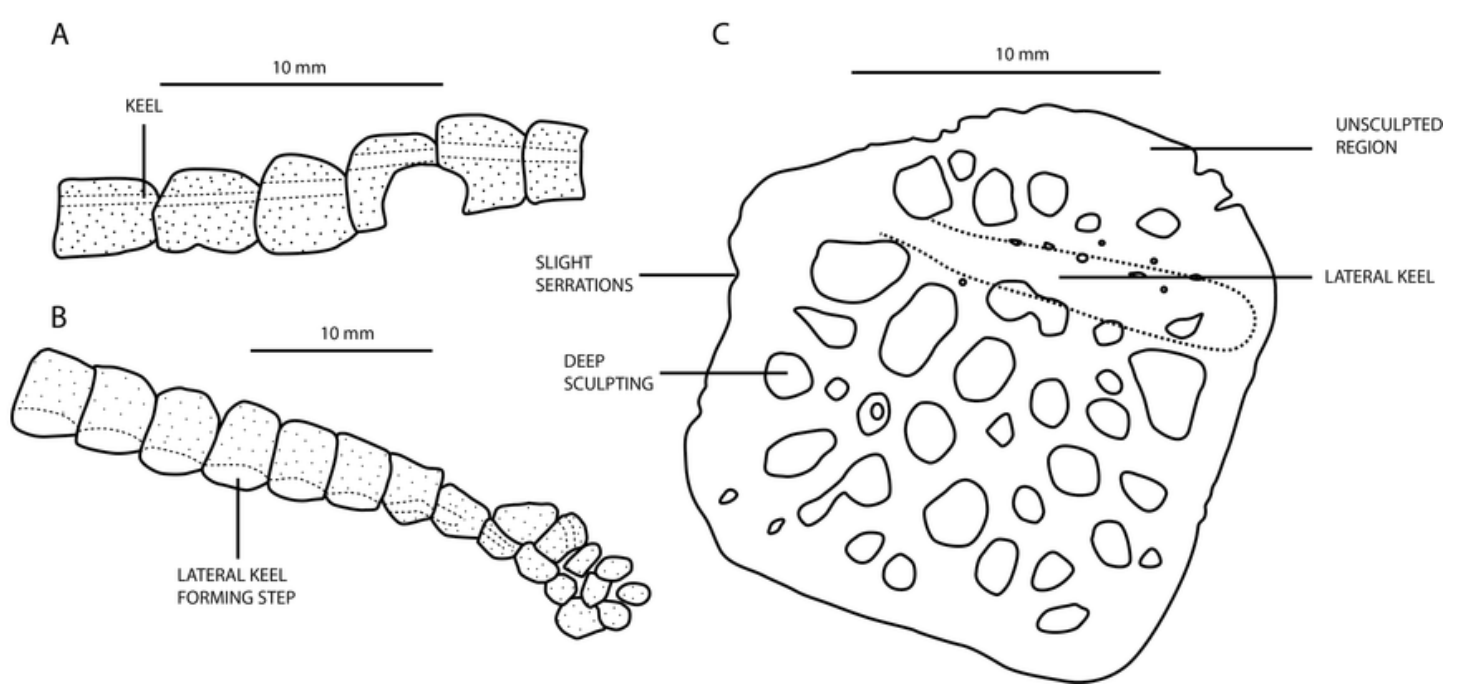




\section{Figure 9}

Figure 9.

Morphometric plots of the holotype specimens of the Late Jurassic atoposaurids

Alligatorellus, Alligatorium, and Atoposaurus. (A) Skull length versus skull width; (B) skull length versus snout length; (C) skull length versus orbit length; and (D) PCA plot for all specimens based on six primary measurements (see text and $\mathrm{S} 1$ for details). Squares represent French taxa, and circles represent German taxa.
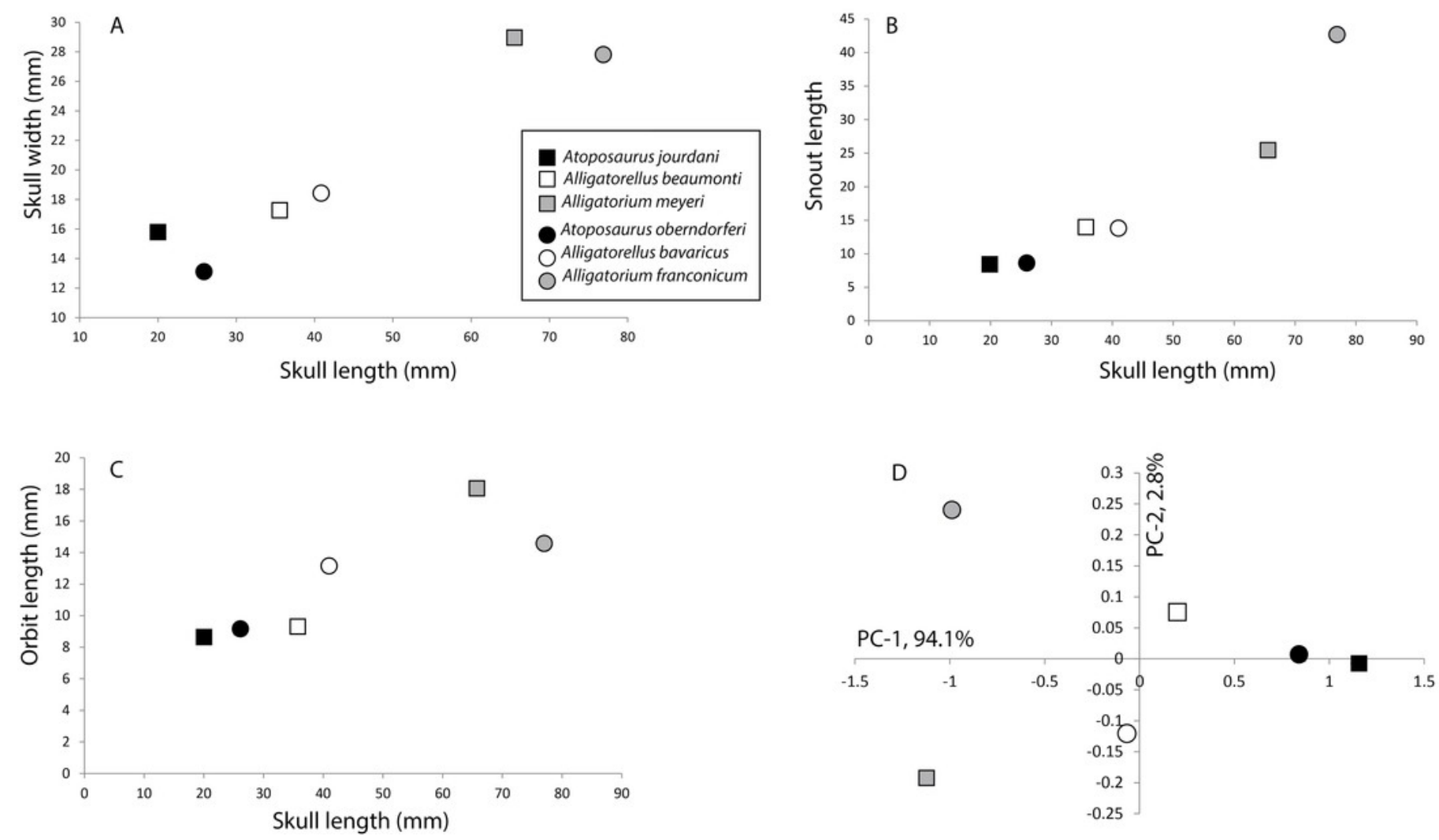